\title{
Višerazinski fiskalni sustav u Bosni: razvoj i suočavanje s gospodarskom krizom
}

\author{
Antić, Dinka
}

Source / Izvornik: Odabrani prijevodi, 2013, 4, 1 - 27

Journal article, Published version

Rad u časopisu, Objavljena verzija rada (izdavačev PDF)

https://doi.org/10.3326/op.19

Permanent link / Trajna poveznica: https:/urn.nsk.hr/urn:nbn:hr:242:051466

Rights / Prava: Attribution-NonCommercial-NoDerivatives 4.0 International/ImenovanjeNekomercijalno-Bez prerada 4.0 međunarodna

Download date / Datum preuzimanja: 2023-04-26

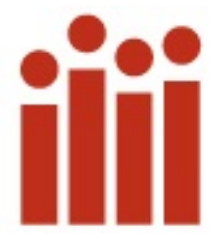

Institute of Public Finance Repository

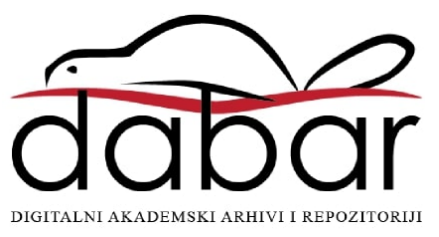


Institut za

javne financije

Smičiklasova 2I | Zagreb

www.ijf.hr | ured@ijf.hr

T: OI/4886-444 | F: OI/48I9-365

\section{ODABRANI}

\section{PRIJEVODI}

ISSN I847-7445

\section{BR. 19/13}

citirati: Antić, D., 20I3. “Multi-level fiscal system in Bosnia and Herzegovina: evolution and coping with economic crisis". Financial Theory and Practice, 37 (3), 279-3IO.

http://www.fintp.hr/upload/files/ft p/2013/3/antic.pdf

Svi Odabrani prijevodi dostupni su na: http://www.ijf.hr/hr/publikacije/ca sopisi/I2/odabrani-prijevodi/III/

\section{VIŠERAZINSKI FISKALNI SUSTAV U BOSNI:}

RAZVOJ I SUOČAVANJE S GOSPODARSKOM KRIZOM

DR. SC. DINKA ANTIĆ*

PREGLEDNI ČLANAK $^{* *}$

JEL: $\mathrm{H}_{7}$

DOI: $10.3326 /$ op.19

\section{SAŽETAK}

Fiskalni federalizam u Bosni i Hercegovini karakterizira asimetrična struktura s više razina vlasti i visokim stupnjem fiskalne decentralizacije. Reforma sustava indirektnog oporezivanja u BiH rezultirala je centralizacijom ključnih prihoda $i$ izuzetno visokim stupnjem međuovisnosti izvršnih vlasti. U nedostatku nacionalnih ekonomskih i fiskalnih ciljeva i fiskalne koordinacije - nužnih tijekom globalne ekonomske krize - do izražaja su došle velike autonomne aktivnosti pojedinih entiteta BiH i Brčko Distrikta. Nekoordinirani i različiti načini odgovorâ na krizu, osim što su narušili već ostvareni stupanj porezne harmonizacije u Bï, rezultirali su povećanjem fiskalnog deficita $s$ izuzetno velikim porastom zaduženosti na svim razinama vlasti. Svrha ovoga rada je predložiti novi model fiskalne koordinacije u BiH koji bi ublažio negativne učinke fiskalne decentralizacije na makroekonomsko upravljanje. Ključna je hipoteza rada da samo koncept fiskalnog federalizma, koji uključuje sveobuhvatnu, institucionalnu i obvezujuću fiskalnu koordinaciju u danim političkim ograničenjima, može jamčiti dosljedan odgovor na krizu.

Ključne riječi: fiskalni odnosi između razina vlasti, fiskalni federalizam, fiskalna koordinacija

"Autorica zahvaljuje trima anonimnim recenzentima na korisnim komentarima i prijedlozima.

** Primljeno: 28. rujna 2012.

Prihvaćeno: II. veljače 20I3.

\section{Dinka ANTIĆ}

Upravni odbor Uprave za indirektno-neizravno oporezivanje Bosne i Hercegovine (UIO),

Odjel za makroekonomsku analizu

Bana Lazarevića bb, 78000 Banjaluka, Bosna i Hercegovina

e-mail: dinka.antic@uino.gov.ba 


\section{UVOD}

Širenje procesa fiskalne decentralizacije $u$ svijetu potaknulo je istraživanja učinkovitosti makroekonomskog upravljanja u fiskalno decentraliziranim zemljama. Mišljenja se ekonomskih stručnjaka o utjecaju decentralizacije na djelovanje makroekonomskog sustava pritom razlikuju. Imajući u vidu tri osnovne funkcije javnih financija - alokaciju, raspodjelu i stabilizaciju (Musgrave, 1959.), Oates, idejni začetnik i kreator teorije fiskalnog federalizma, smatra kako se optimalna učinkovitost sektora države može ostvariti isključivo uravnoteženjem stupnja centralizacije i decentralizacijom fiskalnih nadležnosti između središnje i lokalne vlasti, pri čemu pravednu raspodjelu dohotka i ekonomsku stabilnost treba osigurati središnja država, a učinkovitu uporabu sredstava lokalne vlasti (Oates, 1972.). Kritičari fiskalne decentralizacije (Prud'homme, 1995.) smatraju da pretjerana fiskalna autonomija nižih razina vlasti predstavlja prijetnju održanju makroekonomske stabilnosti i da je u suprotnosti s razumno vođenom makroekonomskom politikom (Tanzi, 20oo.). Nasuprot tome, zagovaratelji većeg stupnja fiskalne decentralizacije vjeruju kako decentralizirani fiskalni sustavi mogu znatno više doprinijeti u upravljanju makroekonomskom politikom, nego što je slučaj s centraliziranim fiskalnim sustavima (Shah, 1997., 2005.). Ipak, i oni ističu nužnost uspostave odgovarajućeg institucionalnog okvira makroekonomskog upravljanja i usvajanja određenih pravila koja bi važila za sve razine vlasti. Usporedne analize učinaka procesa fiskalne decentralizacije u svijetu koje su napravili Ebel i Yilmaz (2002.), Bahl (2006.) te Ter-Minassen (1997.), pokazale su kako makroekonomsku stabilnost složeno uređenih zemalja može ugroziti različita ravnoteža moći između središnje i lokalne vlasti. Teoretičari nove teorije fiskalnog federalizma, tzv. "teorije druge generacije", slabe fiskalne rezultate nekih zemalja objašnjavaju odstupanjem od načela raspodjele odgovornosti za rashode i poreze te slabom središnjom državom (Rodden, 2005.). U situaciji kada u složeno uređenim zemljama postoje snažne regionalne vlasti, fiskalna je koordinacija između razina vlasti ključna odrednica djelovanja fiskalnog federalizma. Weingast (2006.) je definirao pet uvjeta važnih za uspješno djelovanje sustava fiskalnog federalizma: (i) hijerarhija vlasti s jasno određenim opsegom nadležnosti; (ii) autonomija nižih razina vlasti; (iii) jedinstveni ekonomski prostor; (iv) snažna proračunska pravila; i (v) institucionalizacija moći i ovlasti. Ujedno, ti teoretičari smatraju kako uspješno djelovanje fiskalnog federalizma podrazumijeva ravnotežu između autonomije nižih razina vlasti i nadležnosti središnje vlasti, pri čemu svaka razina donosi određene komparativne prednosti. Fiskalni federalizam sa snažnim proračunskim pravilima doprinosi snaženju odgovornosti vlasti za povjerene izvore sredstava i uspostavi fiskalne discipline. Implementacija fiskalnih nadležnosti i pravila ne treba biti prepuštena diskrecionim odlukama središnje vlasti, nego je neophodno uspostaviti institucionalnu strukturu koja će osigurati nesmetano djelovanje fiskalnog federalizma.

Tijekom globalne ekonomske krize je ostvarivanje učinkovitog makroekonomskog upravljanja u decentraliziranim fiskalnim sustavima - umjesto da bude predmetom akademskih istraživanja pretvoreno u ozbiljan problem s kojim se suočavaju izvršne vlasti brojnih zemalja. Uzroke pogoršanja fiskalne situacije u tim je zemljama moguće pronaći u odabranom konceptu fiskalne decentralizacije i globalnim poreznim reformama. Proces fiskalne decentralizacije u svijetu nedvojbeno vodi povećanju fiskalne autonomije nižih razina vlasti. Međutim, iz empirijskog istraživanja Joumarda i Kongsruda 
(2003.) može se zaključiti da je, kao posljedica trenda centralizacije prihoda i uvođenja poreza na dodanu vrijednost, delegiranje ovlasti za rashode bilo znatno brže od delegiranja ovlasti nad porezima. Bahl i Martinez-Vaszquez (2006.) upozoravaju na paradoks fiskalne decentralizacije. Naime, ignoriranje pravila da "financije prate rashode", u provedbi procesa fiskalne decentralizacije, umjesto povećanja fiskalne autonomije nižih razina vlasti, povećalo je njihovu ovisnost o središnjoj vlasti. U složeno uređenim zemljama globalna ekonomska kriza, koja traje od 2008., dodatno je ugrozila održavanje makroekonomske stabilnosti. Trend centralizacije najproduktivnijih i najizdašnijih poreza, povećanje diskrecionih nadležnosti središnje države za okomite transfere nižim razinama vlasti, te delegiranje (spuštanje) nadležnosti za rashode nižim razinama vlasti, posebice onih rashoda čija veličina i trend porasta može ugroziti fiskalnu poziciju središnje države - sve je to niže razine vlasti učinilo izuzetno osjetljivima na ozbiljne proračunske šokove.

Blöchliger (20IOa) je pokazao da je prije ekonomske krize fiskalna pozicija nižih razina vlasti bila znatno stabilnija od pozicije središnje države, što se može objasniti postojanjem snažnih fiskalnih pravila za niže razine vlasti u usporedbi s puno blažim pravilima koja su vrijedila za središnju državu. Unatoč tomu, niže su razine vlasti u ekonomskoj krizi ostvarile deficite zbog tzv. "učinka škara", snažnog pada prihoda, i istovremenog kontinuiranog porasta rashoda, posebice onih za socijalne izdatke. U većini je europskih zemalja "učinak škara" doveo do realnog smanjenja lokalnih proračuna, znatno većeg nego proračuna središnjih vlasti (Davey, 20II.). Analiza ekonomskog učinka krize na proračune u svijetu (Ter-Minassian i Fedelino, 20Io.) pokazuje kako jačina utjecaja tih učinaka na proračune nižih razina vlasti ovisi, primjerice, o snazi gospodarstva i zaposlenosti u regiji/lokalnoj jedinici, strukturi njihovih vlastitih prihoda, ovlastima za rashode koji su osjetljivi na ciklična kretanja, te o strukturi duga. Različito djelovanje krize $u$ pojedinim zemljama rezultat je činjenice da kriza nije sve pogodila $u$ isto vrijeme, te razlike $\mathrm{u}$ administrativnim kapacitetima zemalja u provedbi fiskalnih politika i interventnih mjera (Davey, 20II.). Način odgovora zemalja na izazove koje je donijela kriza u velikoj su mjeri bili određeni stupnjem autonomije pojedine zemlje u pitanjima prihoda i rashoda, ali i mogućnošću intervencije središnje države. Intervencija središnje države uključivala je različite mjere, poput osiguranja dodatnih transfera i zajmova, korištenja akumuliranih financijskih fondova, porasta zaduženja ili privremenog labavljenja postojećih pravila o zaduženju za niže razine vlasti. OECD-ovo istraživanje je pokazalo da su izvršne vlasti nižih razina postupile na različite načine. Iako se u većini država članica središnja vlast odlučila za ekspanzivnu fiskalnu politiku, niže su razine vlasti u polovici zemalja slijedile takvu fiskalnu politiku središnjih vlasti, dok se druga polovica odlučila za rezanje rashoda i povećanje prihoda. Različite fiskalne politike $\mathrm{u}$ vremenu krize, provođene na različitim razinama vlasti $\mathrm{u}$ pojedinim zemljama, ukazuju na važnost postojanja fiskalne koordinacije među različitim razinama vlasti u cilju osiguranja usklađenog i dosljednog odgovora na ekonomsku krizu (Blöchliger, 20IOa). U složeno uređenim zemljama, fiskalna je koordinacija između razina vlasti ključni mehanizam učinkovitog fiskalnog upravljanja, koja ima za cilj usklađivanje regionalnih fiskalnih politika s nacionalnim fiskalnim ciljevima.

Navedeni pregled literature i istraživanja pokazuju da su u vremenu ekonomske krize negativni učinci fiskalne decentralizacije na fiskalnu poziciju i makroekonomsku stabilnost složeno uređenih zemalja 
dodatno produbljeni. Važnost fiskalne politike za makroekonomsko upravljanje u odnosu na druge složeno uređene zemlje još je naglašenija u Bosni i Hercegovini, i to ne samo zbog snažno decentralizirane i asimetrične fiskalne strukture, nego i zbog ograničenih mogućnosti vođenja aktivne monetarne politike u uvjetima postojanja valutnog odbora.

Svrha ovoga rada je prezentiranje modela fiskalne koordinacije koji bi omogućio fiskalnu konsolidaciju višerazinskog sustava i visoko decentralizirane zemlje kao što je $\mathrm{BiH}$, uz ekonomski oporavak i makroekonomsku stabilnost. U drugom dijelu rada, analizom utjecaja reforme neizravnih poreza na nadležnosti u oporezivanju nižih razina vlasti i fiskalnih odnosa između različitih razina, objašnjen je razvoj složenog fiskalnog ustrojstva u BiH od Daytonskog ustava do danas. Treći dio opisuje kvalitetu fiskalnog sustava $\mathrm{u} \mathrm{BiH}$, uz poseban naglasak na analizi fiskalnog upravljanja i uspostavljenim modelima fiskalne koordinacije, te analizi stupnja fiskalne autonomije središnje države i nižih razina vlasti. Fiskalni trendovi prikazani su u četvrtom dijelu, dok je u petom dijelu analizirana fiskalna pozicija BiH i njenih nižih razina vlasti. U šestom su dijelu analizirani glavni nedostaci postojećeg, labavog modela fiskalne koordinacije i suradnje unutar $\mathrm{BiH}$, te je prikazan alternativni model koordinacije. Ovo bi istraživanje trebalo potvrditi hipotezu da jedino obvezna, institucionalna i sveobuhvatna fiskalna koordinacija može doprinijeti fiskalnoj konsolidaciji i ekonomskom oporavku zemlje.

\section{FISKALNA STRUKTURA BOSNE I HERGEGOVINE}

\section{I. OVLASTI IZ DAYTONA (1996. - 2004.)}

Bosna i Hercegovina (BiH) u političkom i fiskalnom pogledu je višerazinska zemlja. Međutim, politički sustav u BiH - u usporedbi s drugim višerazinski organiziranim zemljama - ima donekle poseban ustroj (prilog, slika AI). Sastoji se od dva entiteta: Federacije BiH (FBiH), izrazito decentraliziranog entiteta s tri razine vlasti, Republike Srpske (RS), visoko centraliziranog entiteta s dvije razine vlasti, te Brčko Distrikta (BD), s posebnim statusom. FBiH se sastoji od Io kantona i 8o općina, dok u RS postoje 64 općine. Jedno od obilježja BiH je slaba središnja država na nacionalnoj razini. Prema Daytonskom ustavu, državnoj su razini dodijeljene ograničene nadležnosti nad rashodima, dok su potpune ovlasti dodijeljene entitetima. Brčko Distrikt (uspostavljen 200I.) ima određeni stupanj fiskalne autonomije u području izravnog i neizravnog oporezivanja. Prema Daytonskom sporazumu, od fiskalnih je ovlasti jedino carinska politika i određivanje tarifa bila pod isključivom nadležnosti središnje države, dok je porezna politika, uključujući i sustav socijalnih doprinosa, po pitanju donošenja zakona, administracije i raspodjele prihoda u potpunosti bila u nadležnosti entitetâ. Iako je niz državnih mjera o jedinstvenoj carinskoj politici usvojen još i997., carinska administracija entitetâ i Brčko Distrikta postojala je sve do početka reforme sustava neizravnog oporezivanja. Financiranje administracije na nacionalnoj (središnjoj) razini provođeno je entitetskim proračunskim dotacijama s udjelima od 2/3 FBiH, a I/3 RS. Niže su razine vlasti - u FBiH kantoni, općine i gradovi, a u RS gradovi i općine - financirane poreznim prihodima koje su prikupljali entiteti. Postojanje autonomnih carinskih i poreznih sustava unutar BiH rezultiralo je dvostrukim unutarnjim oporezivanjem ili neoporezivanjem te gubitkom javnih prihoda. 


\subsection{UTJEGAJ REFORMI NEIZRAVNIH POREZA NA POREZNU STRUKTURU}

Reforma neizravnih poreza započela je početkom 2003. osnivanjem međuvladine Komisije za neizravnu poreznu politiku koja je djelovala pod supervizijom međunarodne zajednice. Prva faza reforme završila je u prosincu 2003., nakon usvajanja Zakon o sistemu indirektnog oporezivanja, kojim su ustavne nadležnosti nad politikom neizravnog oporezivanja, administriranja i prikupljanja poreza na prodaju, trošarina i carina prebačene s dva entiteta (FBiH i RS) i Brčko Distrikta na nacionalnu razinu (državu). Tijekom 2004. reforma je u pogledu administracije i poreznog zakonodavstva obuhvatila i konačnu centralizaciju carinske administracije i prijenos odgovornosti nad neizravnim porezima (carine, porezi na prodaju i trošarine) s entiteta i Brčko Distrikta na novoosnovanu državnu agenciju pod nazivom Uprava za indirektno oporezivanje (UIO) i njen Upravni odbor. Koncem 2004., entitetske i zakone Brčko Distrikta zamijenili su novi državni zakoni o porezu na prodaju i carinama, a I. siječnja 2005. u cijelosti su profunkcionirali UIO i jedinstveni račun za prikupljanja neizravnih poreza. U zadnjoj fazi reforme neizravnih poreza (2006.), državni porez na prodaju zamijenjen je porezom na dodanu vrijednost (PDV).

\section{TABLICA I.}

Porezne nadležnosti u Bosni i Hercegovini ${ }^{a}$

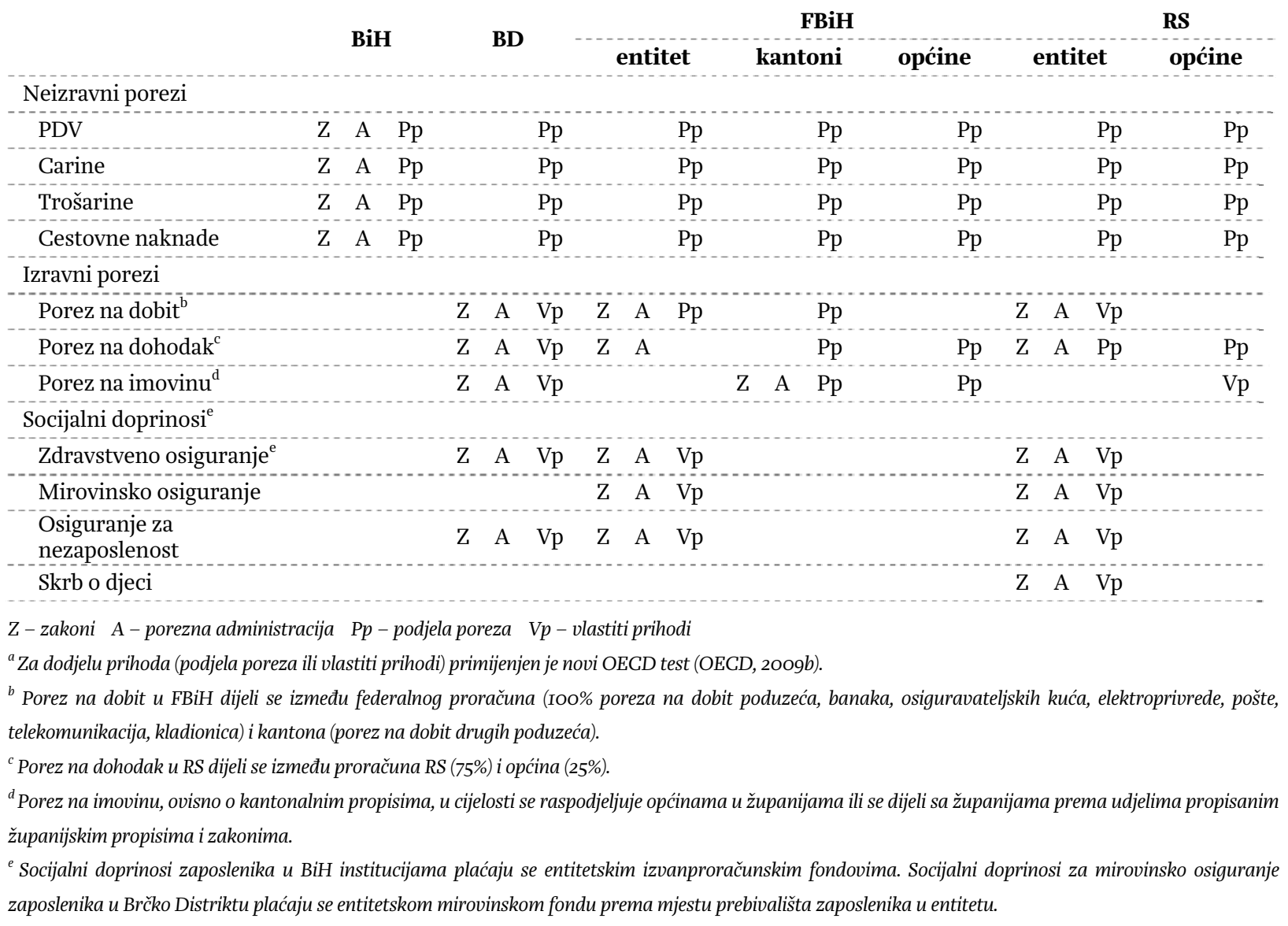

Nakon preustroja poreznih nadležnosti u 2006., u usporedbi s originalnim nadležnostima iz Daytona, izravni su porezi (porez na dohodak, dobit, imovinu, itd.) i socijalni doprinosi ostali $u$ isključivoj 
nadležnosti entitetâ i Distrikta. Ujedno, sve razine vlasti imaju pravo uvesti i različite administrativne pristojbe i neporezne prihode. Pregled poreznih ovlasti u BiH prikazuje tablica I.

Zbog centralizacije prihoda od izravnih poreza, prevladavajućeg izvora prihoda za sve razine vlasti, entiteti nisu više bili u mogućnosti financirati proračun BiH. Stoga je bilo neophodno stvoriti novi sustav okomite raspodjele neizravnih poreza u $\mathrm{BiH}$ kako bi se osiguralo odgovarajuće financiranje institucija BiH, entitetâ i Distrikta. Osim toga, budući da su lokalne vlasti izgubile izvore vlastitih prihoda koji su prešli u sustav oporezivanja PDV-om, bilo je neophodno uspostaviti i novi sustav okomite i horizontalne raspodjele u okviru entitetâ kako bi se osiguralo financiranje njihovih javnih potreba i uravnotežio razvoj općina.

\subsection{RASPODJELA INDIREKTNIH POREZA NA RAZINI BOSNE I HERGEGOVINE}

Sustav financiranja razina vlasti u BiH od prihoda od neizravnih poreza sastoji se od njihove raspodjele na dvije razine. Prva razina raspodjele definirana je državnim Zakon o sistemu indirektnog oporezivanja, a druga entitetskim zakonima.

Neizravni porezi prikupljeni na jedinstveni račun (JR) dnevno se raspodjeljuju prema redoslijedu propisanom Zakonom. Prioritet $\mathrm{u}$ raspodjeli prihoda od neizravnih poreza ima povrat poreznim obveznicima. Proračun $\mathrm{BiH}$ institucija većinom se financira od neizravnih poreza, s malim udjelom vlastitih državnih prihoda (neporezni prihodi, dotacije-grantovi, podjela dobiti Središnje banke i dr.). Istovjetan se iznos s jedinstvenog računa UIO-a svakodnevno plaća proračunu BiH prema iznosu godišnjeg proračuna BiH institucija. Na kraju, preostali iznos dijeli se između entiteta i Brčko Distrikta. Vanjski dug odbija se od iznosa koji ide entitetima prije samog prijenosa, i to u skladu s dinamikom određenom rasporedom o plaćanju Ministarstva financija i Riznice BiH. Plaćanje vanjskog duga prioritetno je u odnosu na proračunske korisnike. Otplata vanjskog duga obveza je entitetâ, a Država BiH jamac je plaćanja obveza prema međunarodnim vjerovnicima. Radi toga se plaćanja po osnovu otplate vanjskog duga izvršavaju dijelom od entitetskih neizravnih poreza, dok samu proceduru plaćanja u ime države kao fiskalni agent BiH provodi Središnja banka. Nakon plaćanja vanjskog duga, ostatak sredstava prebacuje se entitetima.

Raspodjela prihoda od neizravnih poreza propisana je Zakonom o sustavu neizravnog oporezivanja na sljedeći način: dio preostalog iznosa koji se prenosi Federaciji, Republici Srpskoj i Brčko Distriktu utvrđuje se na osnovu njihova udjela u krajnjoj potrošnji prikazanog u prijavama poreza na dodanu vrijednost. Koeficijent raspodjele neizravnih poreza entitetima računa se tako da se krajnja potrošnja FBiH (RS, $\mathrm{BD})$, prikazana u prijavama poreza na dodanu vrijednost, stavlja u odnos s krajnjom potrošnjom na razini BiH. Od I. srpnja 2007., odlukom visokog predstavnika je - u cilju zaštite fiskalne autonomije Distrikta - udio Distrikta u iznosu neizravnih poreza koji se raspodjeljuje entitetima i Distriktu fiksiran na minimalno 3,55\%, odnosno, u nominalnom iznosu do I24 milijuna KM. Od tada koeficijente raspodjele neizravnih poreza entitetima određuje isključivo Upravni odbor UIO. 
Nakon što im se doznači iznos neizravnih poreza, entiteti u skladu sa svojim zakonodavstvom raspodjeljuju sredstva korisnicima (entitetski proračun, kantoni u FBiH, općine i gradovi, Uprava za ceste).

\section{SLIKA I.}

Raspodjela indirektnih poreza u Bosni i Hercegovini

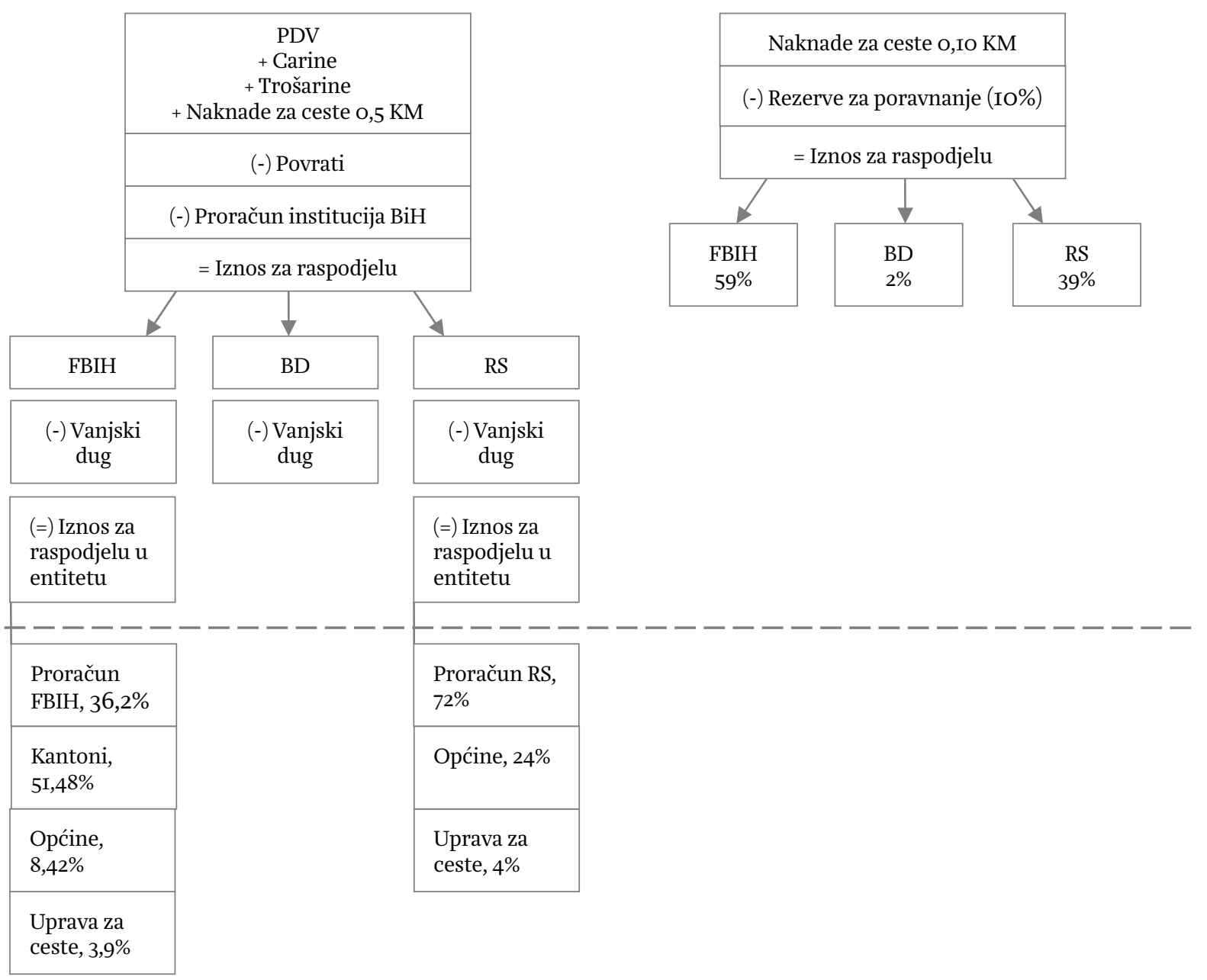

Izvor: Zakon o sustavu neizravnog oporezivanja u BiH (Službeni glasnik BiH, 96/og), Odluka o privremenoj raspodjeli naknada za ceste izdvojene za autoceste (Službeni glasnik BiH, IO2/o9), Zakon o pripadnosti javnih prihoda u FBiH (Službene novine FBiH, 22/o6 i 22/og), Zakon o proračunima (Službeni glasnik RS, I2I/I2).

U međuvremenu je, u cilju financiranja izgradnje mreže autocesta, amandmanima na Zakon o akcizama I. srpnja 2009. uvedena i dodatna naknada za ceste iz cijene naftnih derivata. Raspodjela ove naknade entitetima i Distriktu vrši se prema posebnim koeficijentima koje određuje Upravni odbor UIO-a. Prikaz raspodjele neizravnih poreza pokazuje slika I. (iznad crte).

\section{OBILJEŽJA FISKALNOG SUSTAVA BOSNE I HERGEGOVINE}

\section{I. FISKALNO UPRAVLJANJE}

Temeljno obilježje fiskalnog sustava $\mathrm{BiH}$ je složenost razina vlasti, visok stupanj decentralizacije odgovornosti za prihode i rashode, slaba središnja država te asimetrična struktura entitetskih vlasti, u kojoj je jedan entitet (FBiH) fiskalno decentraliziran, a drugi (RS) centraliziran. Zbog široko dodijeljenog 
stupnja fiskalnog suvereniteta entitetima, fiskalni je federalizam u $\mathrm{BiH}$ u razdoblju nakon rata karakterizirao dualni federalizam. Asimetrija fiskalne strukture BiH dodatno je pojačana uspostavom i dodjelom značajnog stupnja fiskalne autonomije Brčko Distriktu. S druge strane, povoljniji porezni tretman poduzeća u Distriktu, s nižim stopama poreza na prodaju od onih u entitetima, rezultirao je poreznom konkurencijom između razina vlasti unutar BiH. Mnoga su poduzeća - posebice uvoznici naftnih derivata - premjestila svoja sjedišta na područje Distrikta, pa je razdoblje konkurentnog fiskalnog federalizma rezultiralo fiskalnom ekspanzijom Distrikta. Porezna konkurencija između entitetâ i Distrikta okončana je centralizacijom neizravnih poreza na državnom nivou. Reforma sustava neizravnih poreza radikalno je promijenila fiskalne odnose između različitih razina vlasti, ujedno doprinijevši i čvršćem povezivanju ranije autonomnih fiskalnih vlasti. Visok stupanj uzajamne fiskalne međuovisnosti svih razina vlasti je nakon reforme neizravnog oporezivanja potaknuo i pitanje fiskalne koordinacije između različitih razina vlasti u BiH. S druge strane, i zbog procesa europskih integracija potrebno je jedinstvo $\mathrm{BiH}$ (odnosno da "BiH govori jednim glasom"), što u nastalim političkim odnosima podrazumijeva koordinaciju razina vlasti, i to ne samo $u$ fiskalnoj domeni, nego i $u$ svim drugim ekonomskim, političkim i socijalnim pitanjima, što, pak, zahtijeva preuzimanje i implementaciju europskih stečevina (acquis). Zbog svega toga, BiH ulazi u fazu tzv. kooperativnog federalizma koji funkcionira na temelju suradnje svih razina vlasti. U postojećim političkim okolnostima kooperativni je federalizam jedina mogućnost na putu u EU, iako neki autori takav oblik federalizma vide kao "zamku zajedničkog procesa odlučivanja" (Watts, 1998.). Konačno, reforma je neizravnih poreza uspostavom Upravnog odbora UIO-a u fiskalni sustav BiH uključila tzv. izvršni federalizam. Izvršni federalizam je proces u kojemu se veza između razina vlasti odvija putem izvršnih agencija federalne vlasti i regionalnih vlada, kako na političkom tako i na administrativnom nivou (Boadway i Watts, 200o.). Uspostava Upravnog odbora UIO-a u području neizravnih poreza označila je i prijenos ovlasti s Parlamenta na izvršna tijela vlasti. Odlučivanje ministara financija $\mathrm{BiH}$ i entitetâ o politici neizravnih poreza pod Upravnim odborom UIO-a predstavlja izravno uključivanje izvršnih ovlasti u fiskalne odnose među razinama vlasti.

Nakon reforme neizravnih poreza bilo je neophodno uspostaviti i fiskalnu koordinaciju između razina vlasti u BiH. U početku su (2005.) izvršne vlasti, kao oblik neformalne fiskalne koordinacije, osnovale Fiskalno vijeće. Izrazito snažan rast prihoda od neizravnih poreza prouzrokovan uvođenjem PDV-a, rezultirao je velikim suficitom svih razina vlasti, ali, unatoč tome, izvršne vlasti nisu prepoznale potrebu fiskalne koordinacije do trenutka nastanka fiskalnog deficita u 2008. Prema Zakonu o fiskalnom vijeću (Službeni glasnik BiH, 63/o8) uspostavljena je formalna fiskalna koordinacija, ali bez ikakvih institucionalnih kapaciteta. Fiskalno vijeće ima šest članova: predsjedavajući Vijeća ministara $\mathrm{BiH}$ i entitetski premijeri, te državni i entitetski ministri financija. Guverner Središnje banke i predstavnik Vlade Brčko Distrikta u Fiskalnom su vijeću promatrači. Zadaće Fiskalnog vijeća su koordinacija fiskalne politike BiH u cilju osiguranja makroekonomske stabilnosti države, entitetâ i Distrikta. Također, Vijeće usvaja srednjoročni makroekonomski okvir fiskalne politike, koji uključuje fiskalne ciljeve države, entitetâ i Distrikta, makroekonomske projekcije, kao i projekcije kretanja neizravnih poreza i njihove raspodjele $u$ narednim godinama te predložene granice visine duga BiH, 
entitetâ i Distrikta. Fiskalni je cilj ograničen na primarni proračunski suficit/deficit. Odluke Fiskalnog vijeća usvajaju se većinom od pet glasova, ali ta većina mora uključivati najmanje jedan glas od svakog od tri konstitutivna predstavnika. U slučaju pomanjkanja sporazuma o fiskalnom okviru, vlade su dužne podnijeti prijedlog privremenog financiranja u iznosu visine proračuna iz prethodne godine. U slučaju prekoračenja proračuna, Vlada koja je prekršila proračunski okvir mora prebaciti ıo\% od više potrošenog iznosa proračuna kojim se financiraju troškovi za posebne potrebe, iz kojih se vrši otplata unutarnjeg duga Vlade koja je prekršila pravilo.

Postojeći model fiskalne koordinacije ima velike i brojne funkcionalne i suštinske slabosti. Uključivanje premijera u sastav Fiskalnog vijeća umanjuje njegovu učinkovitost, što na koncu može utjecati i da se fokus rada Vijeća prebaci s fiskalnih pitanja na političke rasprave. Nadalje, mehanizam glasovanja, koji uključuje i elemente nacionalizma, može - u slučaju kada jedan narod u Vijeću predstavlja samo jedan član - dovesti do blokade djelovanja Fiskalnog vijeća. Temeljni nedostatak postojeće regulative povezan je sa sveobuhvatnošću fiskalne koordinacije i slabim mehanizmom sankcija. Za razliku od BiH i entitetâ, Distrikt u Fiskalnom vijeću ima ulogu promatrača bez prava odluke, no unatoč tome mora preuzeti sve obveze i može snositi sankcije isto kao i entiteti i država. Kantoni i općine koji zajedno čine oko $28 \%$ ukupnih poreznih prihoda $\mathrm{BiH}$, kao i druge vladine i kvazi-vladine jedinice kao što su izvanproračunski fondovi, u cijelosti su izostavljeni iz sustava koordinacije. Fiskalni je cilj ograničen samo na primarni proračunski suficit/deficit, pri čemu u obračun uopće nisu uzeti kapitalni izdaci i primici. Fiskalni cilj isključuje viškove/manjkove međunarodno financiranih projekata. Definiranjem fiskalnih ciljeva na ovakav način, veliki je dio rashoda izvan kontrole Fiskalnog vijeća, što je plodno tlo za "računovodstvenu gimnastiku". Sankcije, uključujući i izdvajanje Io\% od više potrošenog iznosa na odvojeni račun s kojeg se financira unutarnji dug (npr. stara devizna štednja, materijalna i nematerijalna ratna šteta, itd.), oblik su prisilne štednje države koja - bez obzira na sve - u određenom trenutku mora otplatiti dug, a nikako ne predstavlja kaznu za kršenje dogovorenog okvira. Mehanizam sankcija ne uključuje i osobne sankcije, kao što je to primjer u nekim zemljama (Ter-Minassian, 1997.; Joumard, Kongsrud, 2003.), a što bi se u slučaju BiH moglo pokazati učinkovitijim od postojećeg sustava. Zna li se da je unutarnji dug entitetski dug, to otvara i pitanje učinkovitosti sankcioniranja središnje države BiH i Vlade Distrikta.

Konačno, odluke Fiskalnog vijeća, iako su zakonski uređene, de facto nisu obvezujuće za predsjednika $\mathrm{BiH}$ koji predlaže proračun institucija $\mathrm{BiH}$, Parlamenta $\mathrm{BiH}$ i entiteta koji odobravaju proračune, tako da provedba odluka Vijeća ovisi o ravnoteži moći vladajućih političkih struktura u institucijama koje odlučuju o proračunima.

\subsection{FISKALNA AUTONOMIJA}

Za ocjenu kvalitete fiskalnog federalizma u BiH važno je analizirati strukturu poreznog sustava. Poreznu strukturu BiH karakterizira povijesno nasljedstvo socijalističkog sustava i nizak stupanj ekonomskog razvoja. Rezultat djelovanja ova dva čimbenika je prevladavanje neizravnih poreza. Uvođenje PDV-a dodatno je produbilo jaz između izravnih i neizravnih poreza. Napokon, integracijski 
procesi (CEFTA, EU) umanjili su važnost carina, povećavši utjecaj trošarina. Općenito, svi su ovi čimbenici doprinijeli porastu dominacije neizravnih poreza u poreznoj strukturi BiH (tablica 2).

\section{TABLICA 2.}

Struktura prihoda Bosne i Hercegovine, 2011.

\begin{tabular}{|c|c|c|}
\hline & $\%$ BDP & \% BiH prihoda \\
\hline Neizravni porezi & 19,3 & 43,2 \\
\hline PDV & $\mathrm{I} 2, \mathrm{I}$ & 28,2 \\
\hline Trošarine & 4,9 & II,3 \\
\hline Naknade za ceste & $\mathrm{I}, \mathrm{I}$ & 2,6 \\
\hline Carine & $\mathrm{I}, \mathrm{I}$ & 2,5 \\
\hline Ostalo & $\mathrm{O}, \mathrm{I}$ & 0,2 \\
\hline Izravni porezi & 3,5 & $8, \mathrm{I}$ \\
\hline Porez na dobit & $\mathrm{I}, \mathrm{I}$ & 2,5 \\
\hline Porez na dohodak & 2,0 & 4,7 \\
\hline Drugi izravni porezi & 0,4 & 0,9 \\
\hline Socijalni doprinosi & 15,6 & 36,2 \\
\hline Neporezni prihodi & $5, \mathrm{I}$ & II, 8 \\
\hline Ostalo (ostali prihod, transferi, dotacije) & 0,2 & 0,7 \\
\hline
\end{tabular}

Izvor: Baza podataka Odjela za makroekonomsku analizu Upravnog odbora UIO-a.

Mjerenje stupnja fiskalne decentralizacije u BiH u odnosu na neke druge složeno uređene zemlje na temelju udjela središnje države i nižih razina vlasti u prihodima (tablica 3) pokazuje nisku fiskalnu autonomiju na državnom nivou (središnja država) i izuzetno jaku fiskalnu poziciju srednje razine vlasti, koja se sastoji od entitetâ, kantona i Distrikta (Antić, 2009.).

\section{TABLICA 3.}

Prihodi, u \% BDP-a, 2005.

\begin{tabular}{|c|c|c|c|c|c|c|c|c|}
\hline & Austrija & Belgija & BiH & Kanada & Njemačka & SAD & Španjolska & Švicarska \\
\hline \multicolumn{9}{|l|}{ Porezni prihodi } \\
\hline Opća država & 27,7 & 30,4 & 25,3 & 29,0 & 21,9 & $\mathrm{I} 8,8$ & $2 \mathrm{I}, 4$ & 22,4 \\
\hline Središnja država & 20,4 & 25,8 & 3,0 & $\mathrm{I} 4, \mathrm{O}$ & 10,8 & 9,8 & II, 8 & 10,0 \\
\hline Niže razine vlasti & 7,3 & 4,6 & 22,3 & $\mathrm{I} 5, \mathrm{O}$ & II,I & 9,0 & 9,7 & $\mathrm{I} 2, \mathrm{I}$ \\
\hline \multicolumn{9}{|l|}{ Socijalni doprinosi } \\
\hline Opća država & 16,3 & $\mathrm{I} 6,5$ & $\mathrm{I} 3,2$ & 5,5 & 17,8 & 7,0 & $\mathrm{I} 2,8$ & 7,7 \\
\hline Središnja država & 15,4 & $\mathrm{I} 5, \mathrm{I}$ & & 4,5 & $\mathrm{I} 7, \mathrm{I}$ & 6,8 & $\mathrm{I} 2,7$ & 7,7 \\
\hline Niže razine vlasti & $\mathrm{I}, \mathrm{O}$ & $\mathrm{I}, 4$ & $\mathrm{I} 3,2$ & $\mathrm{I}, \mathrm{O}$ & 0,8 & 0,2 & $\mathrm{O}, \mathrm{I}$ & \\
\hline \multicolumn{9}{|l|}{ Drugi prihodi } \\
\hline Opća država & 4,9 & 4,4 & 5,3 & 6,6 & 3,3 & 5,8 & 2,8 & 8,3 \\
\hline Središnja država & 2,4 & 2,8 & 0,6 & $\mathrm{I}, 2$ & 0,6 & 0,5 & $\mathrm{I}, 5$ & $\mathrm{I}, 6$ \\
\hline Niže razine vlasti & 2,5 & $\mathrm{I}, 6$ & 4,7 & 5,4 & 2,6 & 5,3 & $\mathrm{I}, 2$ & 6,6 \\
\hline
\end{tabular}

Izvor: Antić, 2009.

Usporedba stupnja fiskalne decentralizacije u BiH s nedavnim izračunima MMF-a za 63 zemlje na temelju četiri pokazatelja (Dziobek et al., 20IIa), potvrđuje prethodni nalaz o izuzetno slaboj središnjoj državi u $\mathrm{BiH}$, jer ona, bez obzira o kojoj se kategoriji radilo (europska, unitarna, savezna) ima manje nadležnosti od bilo koje druge promatrane zemlje, izuzev nadležnosti za rashode za plaće zaposlenika (tablica 4). 
TABLICA 4.

Pokazatelji fiskalne decentralizacije, SD/OD ${ }^{a}, 2008$.

\begin{tabular}{|c|c|c|c|c|c|}
\hline $\begin{array}{l}\text { Pokazatelji } \\
(\mathbf{u} \%)\end{array}$ & BiH & Sve zemlje $^{b}$ & $\begin{array}{c}\text { Federalne } \\
\text { (savezne) zemlje }\end{array}$ & $\begin{array}{l}\text { Unitarne } \\
\text { zemlje }^{d}\end{array}$ & $\begin{array}{c}\text { Europske } \\
\text { zemlje }\end{array}$ \\
\hline Prihodi & 8 & 47 & 72 & 90 & $84^{\mathrm{e}-}$ \\
\hline Porezni napor $\mathrm{g}$ & 7 & 48 & 76 & $9 \mathrm{I}$ & $87^{\mathrm{e}}$ \\
\hline Rashodi & 7 & 35 & 62 & $8 \mathrm{I}$ & $73^{-\bar{f}}$ \\
\hline Naknade za zaposlene & 18 & $\mathrm{I} 2$ & 37 & 73 & $59^{\mathrm{f}}$ \\
\hline
\end{tabular}

${ }^{a} \mathrm{SD}=$ središnja država (središnja razina) + državni fondovi za socijalno osiguranje; OD = opća država.

${ }^{b}$ Najniži udio za 63 zemlje.

${ }^{c}$ Prosjek za 8 saveznih zemalja.

${ }^{d}$ Prosjek za 55 saveznih zemalja.

${ }^{e}$ Prosjek za 36 zemalja.

${ }^{f}$ Prosjek za 37 zemalja.

${ }^{g}$ Porezni napor $=$ Porezni prihodi + socijalni doprinosi.

Izvor: BïH - izračun autorice na temelju baze podataka Odjela za makroekonomsku analizu Upravnog odbora UIO-a; Druge zemlje (Dziobek, C. et al., 2OIIa).

Budući da je udio prihoda o kojima u potpunosti (neporezni prihodi) ili djelomice (porez na imovinu) odlučuju općine izuzetno nizak, može se reći i da je fiskalna autonomija općina veoma niska. U cilju određivanja stupnja fiskalne autonomije nižih razina zbog njihove fiskalne ovisnosti o državnim razinama, u analizi fiskalne autonomije nije moguće primijeniti standardnu OECD-ovu sintetičku podjelu (OECD, 2009a). Mjeri li se fiskalna autonomija diskrecijskim pokazateljem (Joumard, Kongsrud, 2003.), koji se računa kao postotak poreznih prihoda nižih razina vlasti, pri čemu državna razina ima IOO\%-tnu kontrolu nad stopom i/ili osnovicom, dolazi se do zanimljivog zaključka da je fiskalna autonomija u BiH prilično niska na svim razinama, te da BiH institucije - kao jezgra središnje države nemaju nikakvu diskrecijsku moć u kreiranju poreznih zakona (tablica 5).

\section{TABLICA 5.}

Stupanj diskrecije nižih razina vlasti, u \%, 2006.

\begin{tabular}{|c|c|c|c|c|c|c|c|}
\hline & $\begin{array}{c}\text { Općine } \\
\text { RS }\end{array}$ & $\begin{array}{c}\text { Proračun } \\
\text { RS }\end{array}$ & $\begin{array}{c}\text { Općine } \\
\text { FBiH }\end{array}$ & Kantoni & $\begin{array}{c}\text { Proračun } \\
\text { FBiH }\end{array}$ & BD & $\begin{array}{l}\text { Ukupni } \\
\text { stupanj }\end{array}$ \\
\hline $2006{ }^{a}$ & 0,47 & 18,84 & 3,78 & 5,07 & 5,23 & 17,78 & I5,43 \\
\hline 2OII. & 0,44 & $23,8 \mathrm{I}$ & 2,97 & $6,5 \mathrm{I}$ & 4,09 & $9,9 I$ & 16,00 \\
\hline
\end{tabular}

${ }^{a}$ Izvor: Antić, 2009.

${ }^{b}$ Izvor: izračun autorice na temelju baze podataka Odjela za makroekonomsku analizu Upravnog odbora UIO-a.

Reforma neizravnih poreza u BiH učvrstila je jedinstveni ekonomski prostor, ali i povećala međuovisnost razina vlasti zbog centralizacije neizravnih poreza koji su glavni izvor financiranja svih razina vlasti u BiH. Međutim, u usporedbi s drugim složeno uređenim zemljama proces centralizacije poreza u BiH nije popraćen i centralizacijom nadležnosti nad rashodima, niti bilo kakvim oblikom jačanja središnje države. Osim reforme obrane i uspostave agencija i uprava (direkcija) potrebnih u procesu europskih integracija, sve su glavne odgovornosti dodijeljene entitetima i kantonima. Entiteti su i dalje, unatoč centralizaciji zakonodavstva i administracije u području neizravnog oporezivanja, zadržali određeni utjecaj na politiku neizravnog oporezivanja putem svojih predstavnika u Upravnom odboru UIO-a. U tom posebnom tijelu entiteti imaju pravo veta na promjene zakonodavstva koje se 
odnose na neizravne poreze koji izvorno pripadaju entitetima (oporezivanje dobara i usluga, trošarine), dok država ima pravo veta na odlučivanje o prihodima od carina koji su u isključivoj nadležnosti BiH. Nadalje, fiskalna autonomija Distrikta zaštićena je Zakonom, iako Distrikt nema prava odlučivanja u okviru Upravnog odbora UIO-a. Poseban utjecaj države i entitetâ u području neizravnih poreza odražava se i u činjenici da bez suglasnosti Upravnog odbora UIO-a nijedan zakon u području neizravnog oporezivanja ne može biti usvojen u Parlamentarnoj skupštini BiH. Unatoč skromnom udjelu prihoda, ojačani su kapaciteti BiH za donošenje odluka, jer državna BiH razina putem Upravnog odbora UIO-a odlučuje o entitetskim udjelima u neizravnim porezima. Istovremeno, glasovanjem u Zastupničkom domu u Parlamentu BiH entiteti izravno utječu na proračun BiH institucija, kao i na visinu dijela proračuna BiH koji se financira s jedinstvenog računa UIO-a.

Opća je ocjena da zbog specifičnog sustava raspodjele neizravnih poreza te niskog udjela izravnih poreza u BiH sve razine vlasti imaju prilično slab stupanj fiskalne autonomije, što za sobom povlači izrazito visok stupanj fiskalne međuovisnosti razina vlasti te potrebu za fiskalnom koordinacijom. Za adekvatnu analizu specifične situacije u BiH bit će neophodno u OECD-ovu tipologiju dodati sljedeći kriterij: stupanj fiskalne autonomije razina vlasti u skupinu dioba poreza (d.5.), koji bi ukazao na način raspodjele prihoda uz suglasnost obje razine vlasti.

\section{FISKALNI TRENDOVI U BOSNI I HERGEGOVINI}

Složena struktura vlasti u BiH doprinijela je pretjeranom rastu javnih usluga i suvišne administracije, prouzročivši umnožavanje i preklapanje javnih usluga, uz gubitak učinkovitosti i djelotvornosti javnog sektora. Relativno visok stupanj javne potrošnje - mjeren u postotku BDP-a - kao rezultat složene političko-teritorijalne organizacije $\mathrm{BiH}$, te visok stupanj fiskalne decentralizacije $\mathrm{BiH}$, također su utjecali na fiskalnu sliku zemlje u obliku visokog poreznog opterećenja. Osim tih čimbenika, na kretanje konsolidiranih prihoda opće države BiH u razdoblju nakon kraja rata (1996.) utjecali su i fiskalni i ekonomski procesi i reforme. Sustavna reforma koja vodi ojačavanju tržišta i smanjenju sive ekonomije, kao što je stvaranje jedinstvenog ekonomskog prostora nakon ukidanja dvostrukog oporezivanja međuentitetske trgovinske razmjene, oporezivanje uvoza trošarinskih dobara na samoj granici, te reforma sustava neizravnog oporezivanja koja je u cijelosti okončana uvođenjem PDV-a, pozitivno je utjecala na rast prihoda $\mathrm{u}$ razdoblju 2004.-08. Osim toga, izuzetno velik rast cijena energenata, sirovina i hrane na svjetskom tržištu tijekom 2008. rezultirao je snažnim nominalnim rastom prihoda od neizravnih poreza (carina, PDV-a), koji su u drugom i trećem tromjesečju 2008. izračunavani ad valorem. No, na drugoj strani bio je prisutan izuzetno snažan pad prihoda od carina zbog pristupanja CEFTA-i (2006.) i potpisivanja Sporazuma o stabilizaciji i pridruživanju EU-a (od I. srpnja 2008., slika 2). 


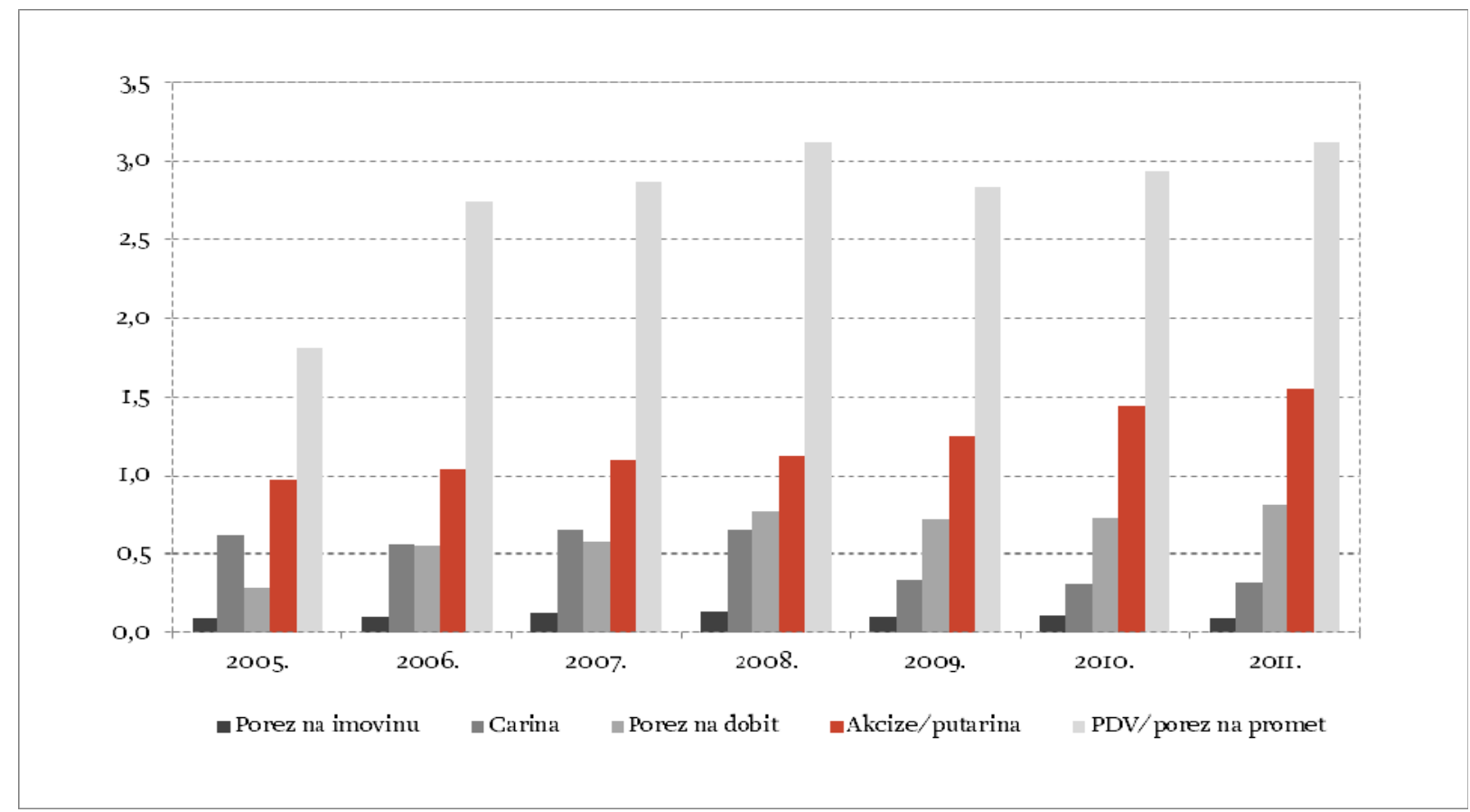

Izvor: Baza podataka Odjela za makroekonomsku analizu Upravnog odbora UIO-a.

Činjenica kako se početak petogodišnjeg razdoblja faznog (postupnog) smanjenja carina na uvoz iz EU-a poklopio s početkom krize, uvelike je zakomplicirala proces fiskalne konsolidacije. Dodatno uvođenje naknada za ceste iz cijene naftnih derivata od I. srpnja 2007. i kontinuirani rast trošarinskih stopa na duhanske proizvode $\mathrm{u}$ skladu s minimalnim EU standardima od 2009., nisu bili dovoljni da bi neutralizirali negativne učinke krize na razinu potrošnje i ekonomske aktivnosti u zemlji. Specifična fiskalna struktura $\mathrm{BiH}$ i proces odlučivanja u okviru Upravnog odbora UIO-a odredili su raspon fiskalnih mjera koje su izvršne vlasti nakon 2008. poduzele u području neizravnih poreza. U PDV-u nije bilo promjena, jer su predložene mjere bile različite, a ovisile su i o ekonomskim i političkim interesima entiteta (npr. FBiH je zagovarala porast opće stope, a RS uvođenje diferenciranih stopa), tako da se jedinstvena $17 \%$-tna stopa nije mijenjala. Ista se situacija dogodila s inicijativom RS-a za uvođenjem "plavog dizela", dok je FBiH zagovarala povrat poljoprivrednicima iz proračuna. Jedini se konsenzus dogodio s postepenim porastom trošarina na cigarete u skladu s minimalnim EU stopama. Određeni pozitivni učinci na prihode od carina očekuju se i 20I3., nakon što Hrvatska pristupi EU-a.

Entiteti i Brčko Distrikt su zbog ovih ograničenih mogućnosti promjena u politici neizravnih poreza mijenjali izravne poreze (porez na dohodak, porez na dobit, porez na imovinu). Reforma izravnih poreza uključivala je, između ostaloga, uvođenje globalnog (sintetičkog) modela oporezivanja dohotka, usklađivanje oporezivanja dobiti s međunarodnom praksom, reformu oporezivanja imovine u RS-u i Brčkom (ukidanje poreza na nasljedstva i darove, uvođenje registra imovine, te određivanje tržišne vrijednosti za poreznu osnovicu), uporabu informatičkih (IT) platformi i procedura, uspostavu jedinstvenog registra obveznika, itd. Navedene su reforme u određenoj mjeri rezultirale unutarnjom harmonizacijom izravnih poreza $\mathrm{u} \mathrm{BiH}$ te nestankom dvostrukog oporezivanja unutar zemlje. 
Reforme izravnih poreza koje su entitetske vlasti provele u razdoblju 2006.-09. dogodile su se tijekom krize i nisu postigle očekivane rezultate (slika 2). Stopa poreza na dohodak u FBiH povećana je s 5 na IO\%, dok je stopa poreza na dobit snižena s 30 na IO\%. RS je mijenjala stopu poreza na dohodak nekoliko puta, da bi ju konačno 20II. povećala s 8 na IO\%. U 20II. je oporezivanje dohotka i dobiti u Distriktu usklađeno s oporezivanjem na razini entiteta, iako i dalje postoje određene razlike u danim izuzećima, odbicima i olakšicama. Primjerice, u FBiH i Distriktu postoji osobni odbitak, dok je u RS-u on 2011. ukinut. RS i Brčko Distrikt su tijekom 20I2. u porezu na dobit uveli porezno izuzeće za ulaganje u proizvodnju i novo zapošljavanje. No, kako loše političko ozračje u BiH obeshrabruje strane ulagače, učinke tih mjera na gospodarstvo i proračune nije moguće predvidjeti. S druge strane, financiranje lokalne razine u RS nesigurno je zbog sveobuhvatne reforme oporezivanja imovine koja je započela $2 \mathrm{OI} 2$.

Rast prihoda od neizravnih poreza pokrenuo je 2006. i 2007. i spiralu troškova složenih administrativnih aparata i socijalnih naknada na svim razinama vlasti (slika 3). Obveze iz kolektivnih sporazuma i zakona o socijalnim pravima veoma su brzo istopile fiskalne viškove iz 2006. i 2007. Uslijed krutosti postojećeg sustava plaća i socijalnih naknada reguliranih entitetskim zakonima, vlade nisu mogle brzo odgovoriti na pad prihoda prouzrokovan ekonomskom krizom i provedbom Sporazuma o stabilizaciji i pridruživanju EU-u. Osim toga, i stand-by aranžman s MMF-om iz 2009. (IMF, 2OIOa) samo je djelomice ispunjen jer izvršna vlast iz političkih razloga nije imala moć provođenja programa štednje.

\section{Slika 3.}

Kretanja prihoda i rashoda u \% BDP-a

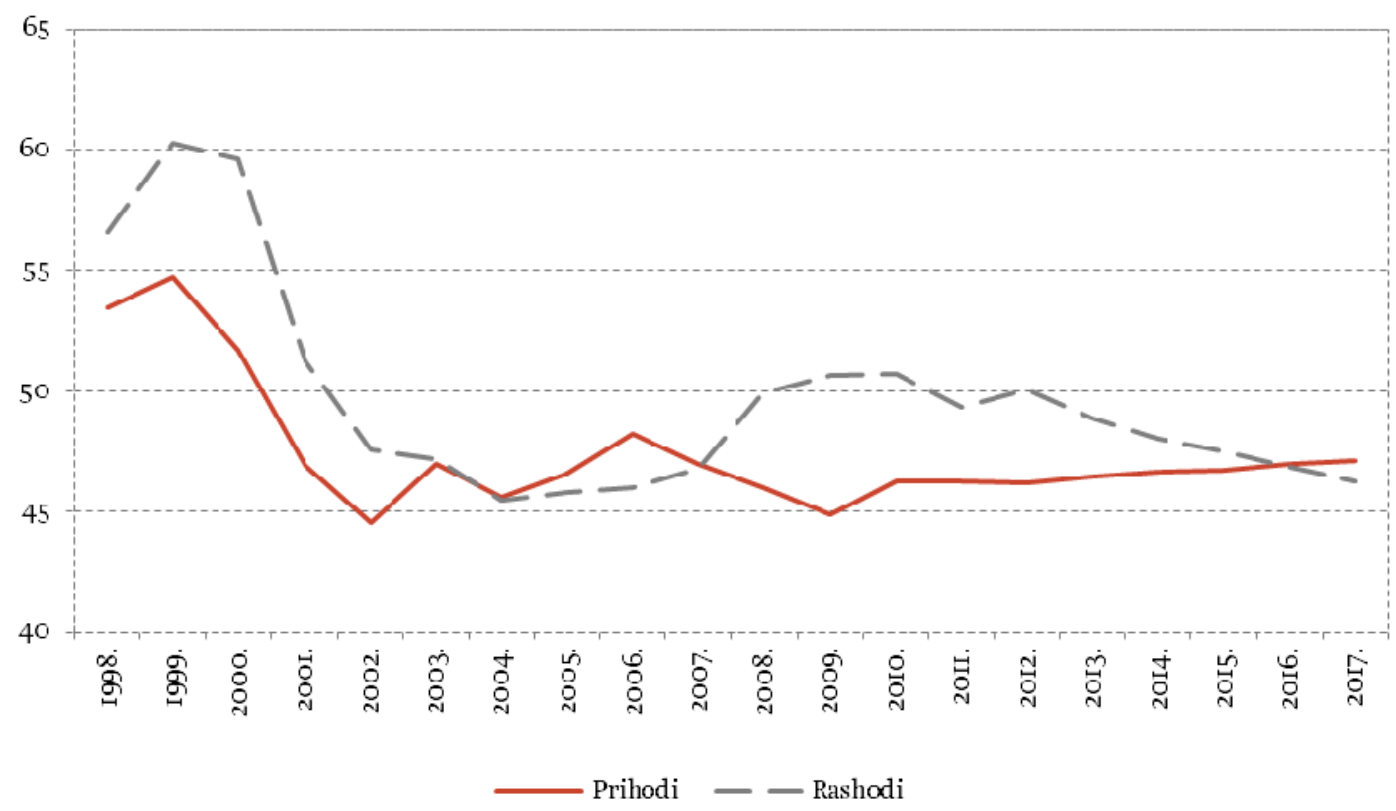

Izvor: IMF, World Economic Outlook Database, 2012. 
Porast troškova uz pad prihoda tijekom 2009. u BiH rezultirao je fiskalnim deficitom od 5,7\% BDP-a, koji je, pak, zbog skromnog porasta prihoda od neizravnih poreza i smanjenja izdataka u skladu s obvezama preuzetim iz sporazuma s MMF-om, u 20Io. iznosio 4,5\% BDP-a, odnosno 3,I\% BDP-a u 201 . Entitetski fiskalni deficiti financirani su primicima od privatizacije (RS) i novim zaduženjem (FBiH, RS) pod nepovoljnim uvjetima. Posljedica takvog postupanja bio je porast ukupnog javnog duga s 31\% BDP-a u 2008. na 43\% BDP-a u 20II. MMF-ove procjene govore kako prije 20I6. BiH neće moći izaći iz ove negativne zone.

\section{FISKALNA POZIGIJA IZVRŠNIH VLASTI U BOSNI I HERGEGOVINI TIJEKOM MEĐUNARODNE} EKONOMSKE KRIZE

\section{I. ČIMBENIGI KOJI UTJEČU NA PRORAČUNE RAZINA VLASTI U BOSNI I HERGEGOVINI}

Pod utjecajem različitih procesa u međunarodnim javnim financijama - centralizacije prihoda i decentralizacije rashoda - danas su mnogi faktori izvan dosega lokalnih i regionalnih vlasti, što u konačnici smanjuje njihove mogućnosti učinkovitih odgovora na izazove ekonomske krize. Istovjetan proces dogodio se izvršnim vlastima u BiH. Smanjenje fiskalnog suvereniteta entiteta i Brčko Distrikta te povećanje ovisnosti o središnjoj vlasti, pojačali su ranjivost proračunske pozicije nižih razina vlasti, u smislu oscilacije prihoda prouzrokovanih međunarodnom krizom. Niže razine vlasti nemaju instrumente utjecaja na ključne izvore prihoda financiranja, a neizravni porezi, kao najsnažnija poluga, prebačeni su na državni nivo. Složenost procedura davanja amandmana na pravila o neizravnim porezima onemogućuje brz odgovor izvršne vlasti na fiskalne poremećaje. S druge strane, okomiti je sustav raspodjele neizravnih poreza izuzetno složen zato što uključuje sve razine vlasti, vanjski dug i povrat neizravnih poreza.

Na fiskalnu poziciju nižih razina vlasti neizravno utječu faktori koji proizlaze iz načina raspodjele neizravnih poreza (slika I). Prvi čimbenik je razina povrata neizravnih poreza. Znajući kako su ti povrati "Ahilova peta" svakog sustava oporezivanja dodane vrijednosti, veći povrati zbog prevara u okviru PDVa izravno smanjuju transfere neizravnih poreza nižim razinama vlasti. Nadalje, i povećanje BiH proračuna smanjuje transfere nižim razinama vlasti, a vrijedi i obratno. Uslijed zastoja u usvajanju BiH proračuna tijekom 20II. udio je BiH institucija zadržan na razini iz 2006., što je omogućilo prebacivanje prihoda od neizravnih poreza ka entitetima i Distriktu.

Model raspodjele prihoda od neizravnih poreza temeljen na krajnjoj potrošnji rezultira slabim ekonomskim kriterijima raspodjele. Postojeća međuovisnost vlada održava se i u fiskalnoj poziciji tako da relativni porast krajnje potrošnje u jednom entitetu - kao rezultat povoljnijih ekonomskih kretanja - vodi smanjenju udjela neizravnih poreza u drugom entitetu, i obratno. Posljedično, izvršne vlasti u izradi proračunskog okvira ne mogu točno predvidjeti udjele u neizravnim porezima, što otežava izradu nacrta proračuna nižih razina vlasti, a proces pregovaranja o proračunskom okviru opće države u BiH čini veoma nesigurnim i nepouzdanim.

Dodatni je problem proces usvajanja koeficijenata raspodjele. Prema trenutno važećim pravilima, Upravni odbor UIO-a svaka tri mjeseca određuje koeficijente raspodjele između entiteta. U slučaju 
neusvajanja takve odluke, primjenjuju se koeficijenti iz prethodnog tromjesečja. Pravila također predviđaju i privremeni obračun (poravnanje, namirenje) za šest mjeseci tekuće godine, te privremeni obračun za proteklu godinu. Nakon vanjske revizije vrši se konačno poravnanje za entitete. Upravni odbor do sada često nije mogao usvojiti nikakav sporazum o koeficijentima, zbog čega su se primjenjivali stari. Budući da su odstupanja stvarnih veća od primijenjenih koeficijenata, izračunati iznosi poravnanja također su veći. Obračuni su nepredvidivi jer su predmet političkih dogovora. Konstantno se usvajaju s određenim vremenskim zaostatkom; u slučaju gomilanja znatnih godišnjih iznosa sredstava po osnovu poravnanja, to bi ugrozilo fiskalnu poziciju entiteta koji treba vratiti sredstva drugom entitetu.

\subsection{ANALITIČKI PRISTUUP}

Kako bi se na najbolji način prikazale promjene $\mathrm{u}$ fiskalnoj poziciji nižih razina vlasti u BiH nakon početka svjetske ekonomske i financijske krize, napravljena je usporedba fiskalnih izvješća svih razina vlasti prije krize, tj. 2008. te 20II., s glavnim stavkama prihoda i rashoda. Analiza fiskalne strukture u BiH može se napraviti horizontalno - dekompozicijom konsolidiranog fiskalnog salda opće države prema središnjoj državi, ali i okomito - dekompozicijom fiskalnih izvješća razina vlasti unutar entitetâ (prilog, slika A2).

Prema MMF-ovoj metodologiji, opća država u BiH sastoji se od središnje države i lokalnih vlasti (IMF, 2005.). Središnja država uključuje proračunske institucije (BiH institucije, proračun $\mathrm{FBiH}$, Io kantona, te proračune RS i Brčko Distrikta), izvanproračunske institucije u entitetima i Distriktu, te izvanproračunske socijalne fondove u entitetima i Distriktu (prilog, slika A3). Lokalna se razina sastoji od 8 o općina u FBiH, odnosno 63 općine u RS. Izvještavanje prema MMF-ovoj metodologiji uključuje i fiskalne operacije entitetskih Uprava za ceste koje se financiraju od neizravnih poreza, te prihode i rashode po osnovi međunarodnih projekata. Službena izvješća vlasti u BiH obično ne uključuju Uprave za ceste i međunarodne projekte, što - imajući u vidu njihovu veliku važnost prema međunarodnim projektima kojima se financira obnova u $\mathrm{BiH}$ - rezultira velikim razlikama između Vladinog i MMF-ovog izvješća o fiskalnom deficitu (trenutno iznose oko $2 \%$ BDP-a).

\subsection{OPǴA DRŽAVA U BOSNI I HERGEGOVINI}

Općenito, najveći udio u prikupljenim prihodima i rashodima opće države u BiH (tablica 6), kao rezultat gospodarskog razvoja i stope rasta stanovništva, odlazi na Federaciju BiH. BDP FBiH iznosi dvije trećine BDP-a BiH. Isto tako, FBiH ima dvostruko više stanovnika od RS, što rezultira i većim socijalnim naknadama i transferima. Nadalje, složena federalna struktura FBiH posljedično je dovela i do visokih administrativnih troškova. Udio kapitalnih izdataka u RS veći je nego u FBiH, što je rezultat različitih ekonomskih kretanja u entitetima proteklih godina, te različitih poreznih i politika ulaganja kao i privatizacije strateških poduzeća u državnom vlasništvu. Proces privatizacije telekomunikacija u RS, netom prije početka krize, donio je značajne izvore sredstava koje je RS uložila u privatna poduzeća, stambenu i izgradnju infrastrukture, pokrivši djelomice manjkove izvanproračunskih fondova i javnih poduzeća (npr. autocesta). S druge strane, udio izravnih poreza gotovo je isti, iako je porezno 
opterećenje u RS poraslo u zadnje tri godine. Reforme u sustavu socijalnih doprinosa povećale su porezno opterećenje u entitetima, a povećan je i udio RS zbog porasta stope i proširenja osnovice.

\section{TABLICA 6.}

Udio razina vlasti, u \% prihoda/rashoda

\begin{tabular}{|c|c|c|c|c|c|c|c|c|}
\hline & \multicolumn{4}{|c|}{2008} & \multicolumn{4}{|c|}{$201 I}$. \\
\hline & ВiH & BD & FBiH & RS & BiH & BD & FBiH & RS \\
\hline Ukupni prihodi & 8,0 & 2,2 & 60,0 & 29,9 & 7,6 & $2, I$ & 57,7 & 32,6 \\
\hline Neizravni porezi & 13,8 & 3,2 & 55,4 & 27,6 & 14,3 & 3,2 & 53,5 & 29,0 \\
\hline Izravni porezi & 0,0 & $\mathrm{I}, 9$ & 56,3 & 41,8 & 0,0 & 1,9 & $5 I, 5$ & 46,7 \\
\hline Porez na dobit & 0,0 & 3,2 & 48,9 & 47,8 & 0,0 & $2, \mathrm{I}$ & 49,7 & 48,2 \\
\hline Porez na dohodak & 0,0 & $\mathrm{I}, 4$ & $57, \mathrm{I}$ & $4 \mathrm{I}, 4$ & 0,0 & 1,9 & 49,8 & 48,4 \\
\hline Drugi izravni porezi & 0,0 & 0,6 & $68, I$ & $3 \mathrm{I}, 3$ & 0,0 & $\mathrm{I}, 2$ & 66,3 & 32,5 \\
\hline Socijalni doprinosi & 0,0 & 0,6 & 69,2 & 30,2 & 0,0 & 0,8 & 65,5 & 33,7 \\
\hline Neporezni prihodi & $7, I$ & 3,3 & 57,7 & $3 \mathrm{I}, 8$ & Io, 6 & 2,2 & 54,0 & 33,2 \\
\hline Ukupni rashodi & 7,2 & $\mathrm{I}, 7$ & 62,3 & 28,8 & 7,8 & 1,9 & 57,8 & 32,5 \\
\hline Troškovi & 7,2 & $\mathrm{I}, 8$ & 62,4 & 28,7 & 8,0 & $\mathrm{I}, 8$ & 58,9 & $3 \mathrm{I}, 3$ \\
\hline Plaće i naknade & 18,2 & 2,3 & 53,5 & 25,9 & 19,5 & 2,4 & 50,2 & 28,0 \\
\hline Uporaba dobara i usluga & 7,8 & 3,4 & 59,9 & 28,8 & 8,7 & 3,7 & 72,3 & 15,4 \\
\hline Dotacije, subvencije & 0,9 & 0,8 & 63,5 & 44,0 & 0,9 & 0,8 & 63,5 & 44,0 \\
\hline Kamate & 0,2 & 0,0 & 50,3 & 49,4 & 0,2 & 0,3 & $59, \mathrm{I}$ & 40,5 \\
\hline Drugi troškovi & 7,2 & 0,0 & 59,7 & $33, I$ & 2,6 & 1,7 & 69,2 & 26,4 \\
\hline Neto stjecanje nefinancijske imovine & 9,3 & $6, \mathrm{I}$ & $4 \mathrm{I}, \mathrm{I}$ & 43,5 & 4,4 & 2,8 & 33,0 & 59,8 \\
\hline
\end{tabular}

Izvor: Baza podataka Odjela za makroekonomsku analizu Upravnog odbora UIO-a.

\subsection{KONSOLIDIRANE SREDIŠNJE VLASTI}

Okomita analiza fiskalne pozicije vlasti u BiH temelji se na dekompoziciji vladinog sektora prema ustavnom ustrojstvu na: BiH institucije, Brčko Distrikt, konsolidiranu FBiH (proračuni FBiH, kantona, općina i gradova te izvanproračunskih fondova), i konsolidiranu RS (proračuni RS, općina i gradova te izvanproračunskih fondova). Analiza struktura rashoda razina vlasti u BiH (tablica 7), izuzev u slučaju institucija BiH i Brčko Distrikta, pokazuje iste udjele neizravnih poreza u entitetima.

\section{TABLICA 7.}

Konsolidirani prihodi središnje države, u \% prihoda

\begin{tabular}{|c|c|c|c|c|}
\hline & $\begin{array}{c}\text { Institucije } \\
\text { BiH }\end{array}$ & BD & $\begin{array}{c}\text { Konsolidirana } \\
\text { FBiH }\end{array}$ & $\begin{array}{c}\text { Konsolidirana } \\
\text { RS }\end{array}$ \\
\hline Neizravni porezi & $8 \mathrm{I}, 2$ & 65,5 & $40, I$ & 38,4 \\
\hline Izravni porezi & 0,0 & 7,2 & 7,2 & II, 6 \\
\hline Porez na dobit & 0,0 & 2,5 & 2,2 & 3,8 \\
\hline Porez na dohodak & 0,0 & 4,2 & 4,0 & 6,9 \\
\hline Drugi izravni porezi & 0,0 & 0,5 & $\mathrm{I}, \mathrm{O}$ & 0,9 \\
\hline Socijalni doprinosi & 0,0 & $\mathrm{I} 4,4$ & $4 \mathrm{I}, \mathrm{I}$ & 37,4 \\
\hline Neporezni prihodi & 16,5 & $\mathrm{I} 2,5$ & II,I & $\mathrm{I} 2, \mathrm{O}$ \\
\hline $\begin{array}{l}\text { Ostalo (drugi prihodi, } \\
\text { transferi, dotacije) }\end{array}$ & 2,2 & 0,3 & 0,6 & 0,6 \\
\hline $\begin{array}{l}\text { Ukupno } \\
\end{array}$ & IOO,O & 100,0 & IOO,O & IOO,O \\
\hline
\end{tabular}

Napomena: Uključeni su svi drugi korisnici raspodjele neizravnih poreza u BiH, izuzev Uprave za ceste. Izvor: Izvješća Odjela za makroekonomsku analizu Upravnog odbora UIO-a, www.oma.uino.gov.ba. 
Budući da je Federacija BiH fiskalno složena struktura, zanimljivo je analizirati raspodjelu prihoda prema razinama vlasti unutar FBiH (tablica 8). Očito je kako su proračuni FBiH i kantona uglavnom osjetljivi na porast neizravnih poreza, dok su kantoni najosjetljiviji na kretanje izravnih poreza. Glavni izvor prihoda općina u BiH su neporezni prihodi i porez na imovinu.

\section{TABLICA 8.}

Konsolidirani prihodi FBiH prema razini vlasti, u \% prihoda, $20 I I$.

\begin{tabular}{|c|c|c|c|}
\hline Vrsta prihoda & $\begin{array}{c}\text { Proračun } \\
\text { FBiH }\end{array}$ & Kantoni & Općine \\
\hline Izravni porezi & $\mathrm{IO}, \mathrm{O}$ & 65,7 & 24,3 \\
\hline Porezi na dohodak i dobit & $\mathrm{I} 2, \mathrm{O}$ & 73,6 & 14,4 \\
\hline Porez na dohodak fizičkih osoba & $\mathrm{O}, \mathrm{O}$ & 77,4 & 22,6 \\
\hline Porezi na dobit poduzeća & $\mathrm{O}, \mathrm{O}$ & 99,9 & O,I \\
\hline Ostali porezi na dohodak & IOO,O & $\mathrm{O}, \mathrm{O}$ & $\mathrm{O}, \mathrm{O}$ \\
\hline Porezi na platnu listu i radnu snagu & $\mathrm{O}, \mathrm{O}$ & 70,6 & 29,4 \\
\hline Porezi na imovinu & $\mathrm{O}, \mathrm{O}$ & $\mathrm{I} 6,2$ & 83,8 \\
\hline Neizravni porezi (uključujući i naknade za ceste) & 42,2 & 50,4 & 7,5 \\
\hline Ostali porezi & $\mathrm{I}, 8$ & 67,7 & 30,6 \\
\hline Neporezni prihodi & 29,2 & 33,9 & $3 I, 6$ \\
\hline
\end{tabular}

Analiza fiskalne pozicije konsolidiranih entitetskih vlasti u 20II., u usporedbi s 2008. (prilog, tablica AI), mjerena kao udjel u BDP-u, pokazuje trend smanjenja prihoda u FBiH i povećanja prihoda u RS, što je rezultat poreznih reformi provedenih $\mathrm{u}$ entitetima te rasta koeficijenata raspodjele neizravnih poreza $\mathrm{u}$ korist RS. Fiskalna konsolidacija koju je MMF nametnuo stand-by aranžmanom iz 2009. (IMF, 20IOa), dovela je do rezanja rashoda $\mathrm{u} \mathrm{FBiH}$, $\mathrm{i}$ to većinom na stavci socijalnih naknada i transfera nižim razinama vlasti. Nasuprot tomu, u RS je bio prisutan porast rashoda potaknut financiranjem po osnovi primitaka od privatizacije telekomunikacija.

\subsection{NIŽE RAZINE VLASTI U ENTITETIMA}

Analiza fiskalne pozicije nižih razina vlasti u 20II., u usporedbi s 2008., temelji se na fiskalnim izvješćima za svaku razinu vlasti (entitetski proračuni, kantoni u FBiH, općine i gradovi). Sveobuhvatna analiza financiranja lokalnih vlasti u europskim zemljama tijekom krize (Davey, 20II.) pokazuje da su prihodi na višim razinama vlasti više podložni promjenama od prihoda na nižim, lokalnim razinama. No, podaci iz oba BiH entiteta pokazuju suprotne trendove. Iz konsolidiranih izvješća (prilog, tablica A2), $u$ odnosu na proračun Federacije u kojoj su prihodi porasli, vidljiv je negativan trend smanjenja nominalnih prihoda na razini kantona u FBiH. Prihodi kantona i općina niži su nego u 2008. zbog smanjenja poreza na dohodak. Osim toga, lokalna razina u BiH pogođena je i značajnim smanjenjem poreza na imovinu, (iako je to specifičan porez, a plaća se prema području u kojem se imovina nalazi), te smanjenjem subvencija i transfera iz Federacije i kantona. Pad međuvladinih dotacija nižim razinama vlasti bio je veći od smanjenja vlastitih poreznih prihoda, što je u skladu sa zaključkom OECD-ove analize o tome kako su međuvladine dotacije podložni većim promjenama od vlastitih poreznih prihoda (Blöchliger, 20IOa). 
Federalna razina značajno je smanjila rashode, što je - uz porast prihoda - smanjilo njen fiskalni deficit. Smanjenje rashoda vidljivo je i na razini kantona, ali u manjem omjeru. Analiza strukture rashoda pokazuje da je to smanjenje napravljeno na stavkama dotacija, subvencija i transfera nižim razinama vlasti, te na kapitalnim rashodima. Nasuprot tomu, plaće na razini FBiH i kantona nisu smanjene, dok su materijalni rashodi smanjeni samo u manjem obujmu. Zanimljivo je da je lokalna razina povećala izdatke za plaće i troškove za socijalne naknade koje su u nadležnosti općina.

U usporedbi s 2008., RS je, zbog povećanja udjela od raspodjele neizravnih poreza i dovršenih sporazuma za razdoblje 2009.-II., ostvarila nominalan porast prihoda na razini proračuna entiteta (prilog, tablica A3). No, zbog manjih transfera od neizravnih poreza, smanjenja poreza na imovinu i neporeznih prihoda, općine su prikupile manje prihoda. Porast stopa socijalnih doprinosa, ukidanje osobne olakšice u okviru poreza na dohodak, te uvođenje fiskalnih blagajni u RS koje je počelo 20og., doveli su do zatvaranja brojnih malih poduzeća (obrta), što je smanjilo i porezne i neporezne prihode proračuna RS i općina.

Fiskalna pozicija proračuna RS poboljšana je 20II. porastom prihoda i smanjenjem rashoda, a fiskalni je deficit lokalne razine također smanjen. Fiskalnom konsolidacijom u RS značajno su smanjeni rashodi proračuna RS. Smanjenje rashoda provedeno je na materijalnim rashodima, dotacijama i socijalnim transferima, dok su rashodi za plaće i kapitalne izdatke povećani. Općine su zadržale rashode za plaće na istoj razini, istovremeno smanjivši dotacije, socijalne transfere i kapitalne izdatke.

\section{KRIZA KAO POTICAJ ZA REFORMU KONGEPTA FISKALNE KOORDINAGIJE U BOSNI I}

\section{HeRGEGOVINI}

Vrijeme od pojave krize do danas ukazalo je na sve slabosti postojećeg sustava fiskalne koordinacije u $\mathrm{BiH}$. Autonomne reforme izravnih poreza koje su proveli entiteti ugrozile su zaposlenost, strana ulaganja i dostignuti stupanj unutarnje porezne harmonizacije. Slaba središnja vlast na nacionalnoj razini i labava fiskalna koordinacija unutar Fiskalnog vijeća nisu mogli utjecati na politiku plaća i socijalnih naknada na razini entitetâ i lokalnih jedinica niti spriječiti povećanje stupnja neusklađenosti entitetskih poreznih politika. Politička previranja u zemlji spriječila su Fiskalno vijeće u određivanju državnog udjela neizravnih poreza u BiH, usvajanju fiskalnih ciljeva i srednjoročnog okvira za BiH za razdoblje 2OII.-I4., zbog čega su institucije BiH bile u sustavu privremenog financiranja tijekom cijele 20II., a entiteti su morali samostalno izrađivati svoje proračune. Proračunska kriza kulminirala je početkom 20I2. kada je neusvajanje proračuna $\mathrm{BiH}$ institucija za 20I2. dovelo do zamrzavanja otplata vanjskog duga, iako su sredstva od raspodjele neizravnih poreza bila pripremljena za tu svrhu. Pa ipak, kako bi se ispunili zahtjevi za dobivanje financijske pomoći EU-a, MMF-a i Svjetske banke, Fiskalno je vijeće u svibnju 20I2. uspjelo postići dogovor o srednjoročnoj raspodjeli neizravnih poreza za proračun BiH institucija, te donijeti sveopći fiskalni okvir za opću državu u BiH za razdoblje 20I2.-I5.

Porast duga i spor ekonomski oporavak na jednoj, te različite fiskalne mjere usvojene tijekom 20I2. s nesigurnim učincima na drugoj strani, bez rezanja trenutnih rashoda, mogli bi u uvjetima postojeće labave i povremene fiskalne koordinacije - koju često zahtijeva i međunarodna zajednica - dovesti do 
daljnjeg produbljivanja fiskalnog deficita nižih razina vlasti u BiH. Čak štoviše, odustajanje od postizanja dogovora oko jedinstvene gornje granice duga u BiH u okvirima od I8\% ukupnih prihoda $u$ ljeto 2OI2., vlasti je u RS primoralo na određivanje granice duga u odnosu na BDP, što je i u tome entitetu stvorilo daljnji prostor za posuđivanje. U uvjetima porasta zaduženja i niskog kreditnog rejtinga, vlade su u rujnu 20I2. postigle novi sporazum s MMF-om u iznosu od 4IO milijuna eura. Glavne obveze preuzete tim novim stand-by aranžmanom, između ostalih, uključuju smanjenje plaća, socijalnih naknada i subvencija, kvalitetnije ciljanje i odabir socijalnih politika, uspostavu učinkovitije fiskalne koordinacije i srednjoročnog fiskalnog planiranja, uklanjanje prepreka u raspodjeli neizravnih poreza te financiranje proračuna $\mathrm{BiH}$ i vanjskog duga (IMF, 2OI2.). Nametnute obveze $\mathrm{BiH}$ su s točke gledišta smanjenja državne potrošnje, ojačavanja pozicije države u fiskalnim odnosima te provođenja dugo očekivanih reformi politike rashoda obećavajuće i za građane. Napokon, sve bi to trebalo olakšati i fiskalnu poziciju nižih razina vlasti, te osigurati efikasan i nepristran sustav socijalnih naknada u BiH. Ipak, zbog strožih zahtjeva za otplatu sljedeće MMF-ove tranše, upitnim bi mogao postati sporazum postignut u okviru Fiskalnog vijeća u svibnju 2012.

Činjenica da u protekle četiri godine Fiskalno vijeće nije osiguralo usklađen i koordiniran fiskalni odgovor na globalnu ekonomsku krizu ukazuje na potrebu ozbiljnih reformi postojećeg koncepta fiskalne koordinacije. Reformirani model fiskalne koordinacije $\mathrm{u} \mathrm{BiH}$ trebao bi istovremeno biti politički održiv, ekonomski učinkovit te biti u mogućnosti predvidjeti buduće obveze $\mathrm{BiH}$ u procesu pristupanja EU-u. Budući da zbog specifičnih političkih i fiskalnih odnosa BiH više sliči samom EU-u nego drugim složeno uređenim zemljama, reformirani bi model trebao biti utemeljen na konceptu harmonizacije i koordinacije koji podržavaju EU članice (Šimović, 2007.), tj. trebao bi biti utemeljen na konceptu kooperativnog fiskalnog federalizma. Međutim, za razliku od drugih složeno uređenih EU zemalja s razvijenom demokracijom, visokim stupnjem fiskalne odgovornosti, u kojima izvršne vlasti poštuju obveze koje proistječu iz nacionalnih fiskalnih sporazuma, bez da je fiskalna koordinacija uopće i potrebna (European Commission, 20I2.), politički dogovori za vlade u BiH nisu dovoljni, nego moraju biti zakonom obvezni kako bi se poštivali fiskalni ciljevi i okvir. Kako bi odluke Fiskalnog vijeća u smislu fiskalnih okvira, bile obvezujuće za Predsjedništvo i Parlament, nužna je institucionalizacija Fiskalnog vijeća u obliku izvršnog federalizma koji bi uključio mehanizam donošenja odluka, istovjetan s postojećim mehanizmom glasovanja Upravnog odbora UIO-a. Usvajanju fiskalnog cilja i proračunskog okvira trebala bi prethoditi rasprava koja bi nužno uključila i odbore za proračun BiH Parlamenta i entitetâ, većinu kantona, udruženja općina i najveće izvanproračunske fondove. Reforma sustava fiskalne koordinacije u BiH trebala bi također uključiti i redefiniranje fiskalnog cilja u smislu njegova određenja po pitanju konsolidiranih prihoda i rashoda (tekućih i kapitalnih) svih razina administracije, uključujući i deficite u međunarodnim projektima, poslovanje općina, razvojnih banaka u državnom vlasništvu i poduzeća koja su velikodušno financirana putem proračuna (npr. autoceste), te propisivanje jedinstvene granice zaduživanja za $\mathrm{BiH}$ i entitete. Automatiziranje postojeće raspodjele neizravnih poreza bez intervencije Upravnog odbora UIO-a značajno bi olakšalo rad Fiskalnog vijeća, a proračunske bi projekcije nižih razina vlasti učinilo pouzdanijim i vjerodostojnijim. Konačno, efikasnost fiskalne koordinacije ne može se postići bez fiskalne discipline na svim razinama vlasti, 
učinkovitog nadzora fiskalnih operacija te sankcija za neispunjavanje obveza iz fiskalnog okvira za kolektive i odgovorne pojedince u vlastima.

\section{ZAKLJUČAK}

Kriza je potvrdila mišljenje teoretičara kako je raspodjela glavnih odgovornosti između različitih razina administracije u složeno uređenim zemljama, a koju zagovara teorija fiskalnog federalizma, nedovoljna u sprečavanju negativnog utjecaja fiskalne decentralizacije na makroekonomsko upravljanje. Zbog toga je neophodno uvesti fiskalnu koordinaciju kao "institucionalno ljepilo", kojim bi se uskladili proračuni i fiskalno djelovanje svih razina vlasti s nacionalnim fiskalnim ciljevima.

Analiza fiskalnog sustava $\mathrm{BiH}$, njegovo djelovanje i odgovor na krizu ukazali su na ključne nedostatke složenog i visoko decentraliziranog fiskalnog sustava u BiH. Autonomna i nekoordinirana postupanja entitetâ u vremenu gospodarske krize pogoršala su fiskalnu poziciju BiH. Postojeći model labave fiskalne koordinacije, temeljene na političkom dogovoru entiteta, a koju uobičajeno zahtijeva međunarodna zajednica, doveo je do privremenog izvršavanja obveza izvršnih vlasti. Različito funkcioniranje fiskalnog sustava u BiH koje je gurnulo zemlju u zaduženost i ugrozilo perspektive gospodarskog oporavka, povećalo je potrebu izgradnje alternativnog modela fiskalne koordinacije kojim bi se entitetske fiskalne politike uskladile s nacionalnim fiskalnim ciljevima.

Pretpostavka ovoga rada bila je da jedino sveobuhvatna, institucionalna i obvezujuća fiskalna koordinacija između razina vlasti može osigurati usklađen odgovor BiH na izazove koje donosi ekonomska kriza.

Imajući u vidu složeno fiskalno uređenje i ozbiljna politička ograničenja, neophodno je uspostaviti višerazinski sustav fiskalne koordinacije koji će sve zainteresirane strane uključiti u proces pregovaranja oko proračunskih okvira i nacionalnih fiskalnih ciljeva.

Drugim riječima, takvi zahtjevi za institucionalizacijom fiskalne koordinacije znače da bi se Fiskalno vijeće iz pukog političkog tijela trebalo preobraziti u ključnu financijsku instituciju koja će odlučivati o sveukupnoj nacionalnoj fiskalnoj politici.

Da bi alternativni model fiskalne koordinacije uopće bio ostvariv, trebao bi ispuniti dva uvjeta: usklađivanje visokog stupnja fiskalne autonomije entitetâ i potreba za kvalitetnijim makroekonomskim upravljanjem državne vlasti. U ispunjavanju tih uvjeta novi bi model fiskalne koordinacije u BiH trebao u obzir uzeti temeljna obilježja kooperativnog i izvršnog fiskalnog federalizma. U svakom slučaju, suradnja između državne razine i entitetâ, uspostavljena u okviru Fiskalnog vijeća, neophodna je, ali ne i dovoljna da bi se izvršne vlasti pridržavale nacionalnih fiskalnih ciljeva. Za razliku od drugih složeno uređenih zemalja, u kojima su savezne vlade odgovorne za proces fiskalne koordinacije i nadzor nad fiskalnim djelovanjem nižih razina vlasti, državna razina u BiH nije dovoljno snažna da bi mogla voditi takav proces. Znajući da državnoj razini nije moguće delegirati dodatne fiskalne ovlasti za makroekonomsku politiku bez sveobuhvatnih i temeljitih promjena Ustava, neophodno je $u$ međuvladine fiskalne odnose u BiH ugraditi izvršni fiskalni federalizam, na sličan način kako je 
učinjeno u sustavu neizravnog oporezivanja. Zbog toga je Fiskalnom vijeću nužno dodijeliti izvršne fiskalne ovlasti u uspostavi nacionalnih fiskalnih ciljeva, fiskalnih pravila i proračunskog okvira, koji bi bili obvezujući za sve razine vlasti i njihove parlamente. To bi pomoglo ne samo procesu fiskalne koordinacije i ekonomskim ostvarenjima nego i smanjenju političkih napetosti u zemlji i bržem ispunjenju obveza u procesu EU integracija.

S engleskoga preveo: Vjekoslav Bratić Institut za javne financije 


\section{SLIKAAI.}

Politički ustroj Bosne i Hercegovine

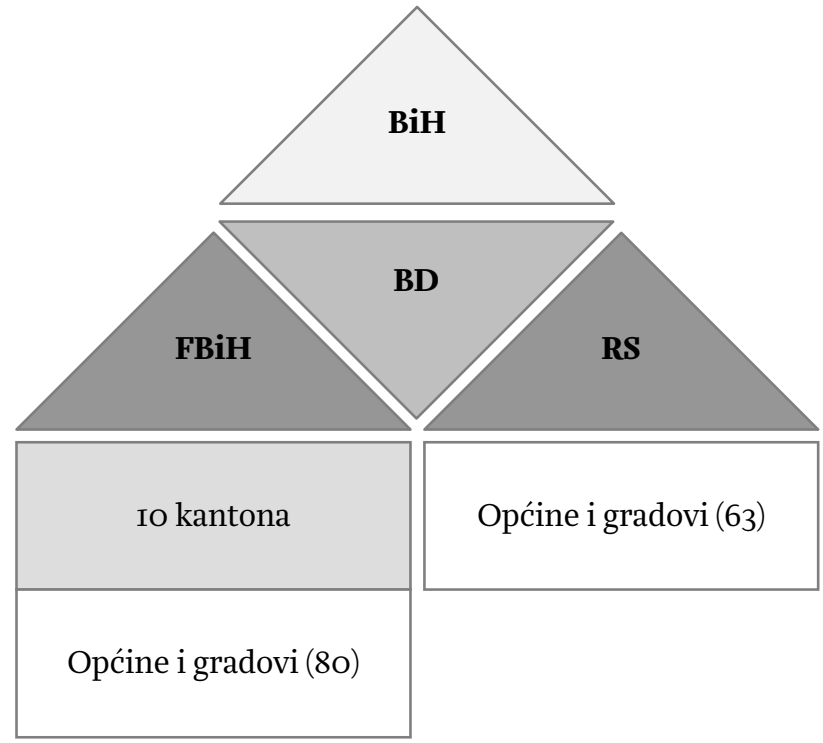

Skraćenice:

$\mathrm{BiH}$ - Bosna i Hercegovina

FBiH - Federacija Bosne i Hercegovine RS - Republika Srpska

BD - Brčko Distrikt

\section{SLIKA A2.}

Razine središnje vlasti u Bosni i Hercegovini

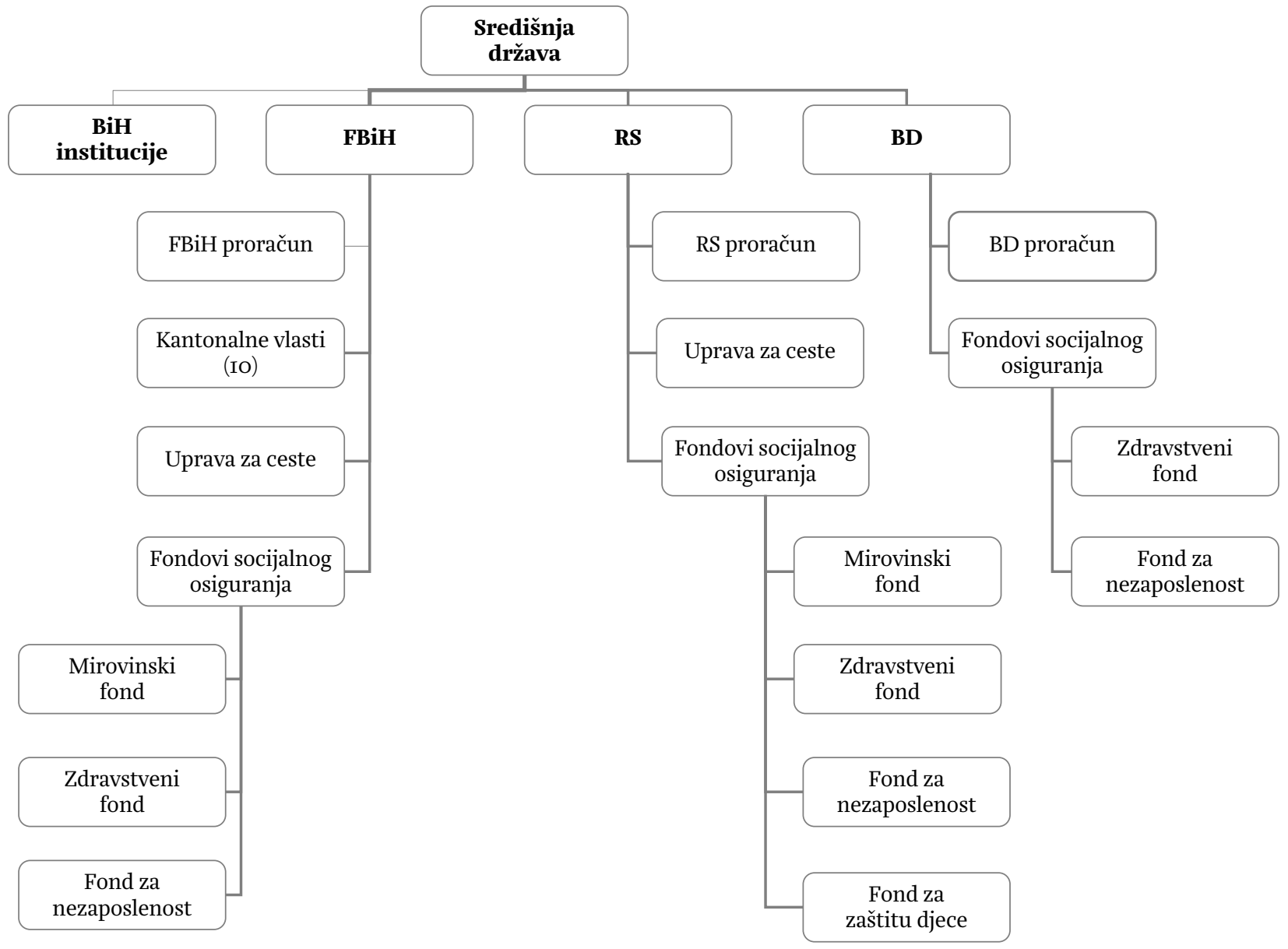

Napomena: Prezentacija je temeljena na IMF GFS analitičkom pristupu. Izvor: IMF, 2005. 
SLIKA A3.

Institucionalne razine opće države u Bosni i Hercegovini

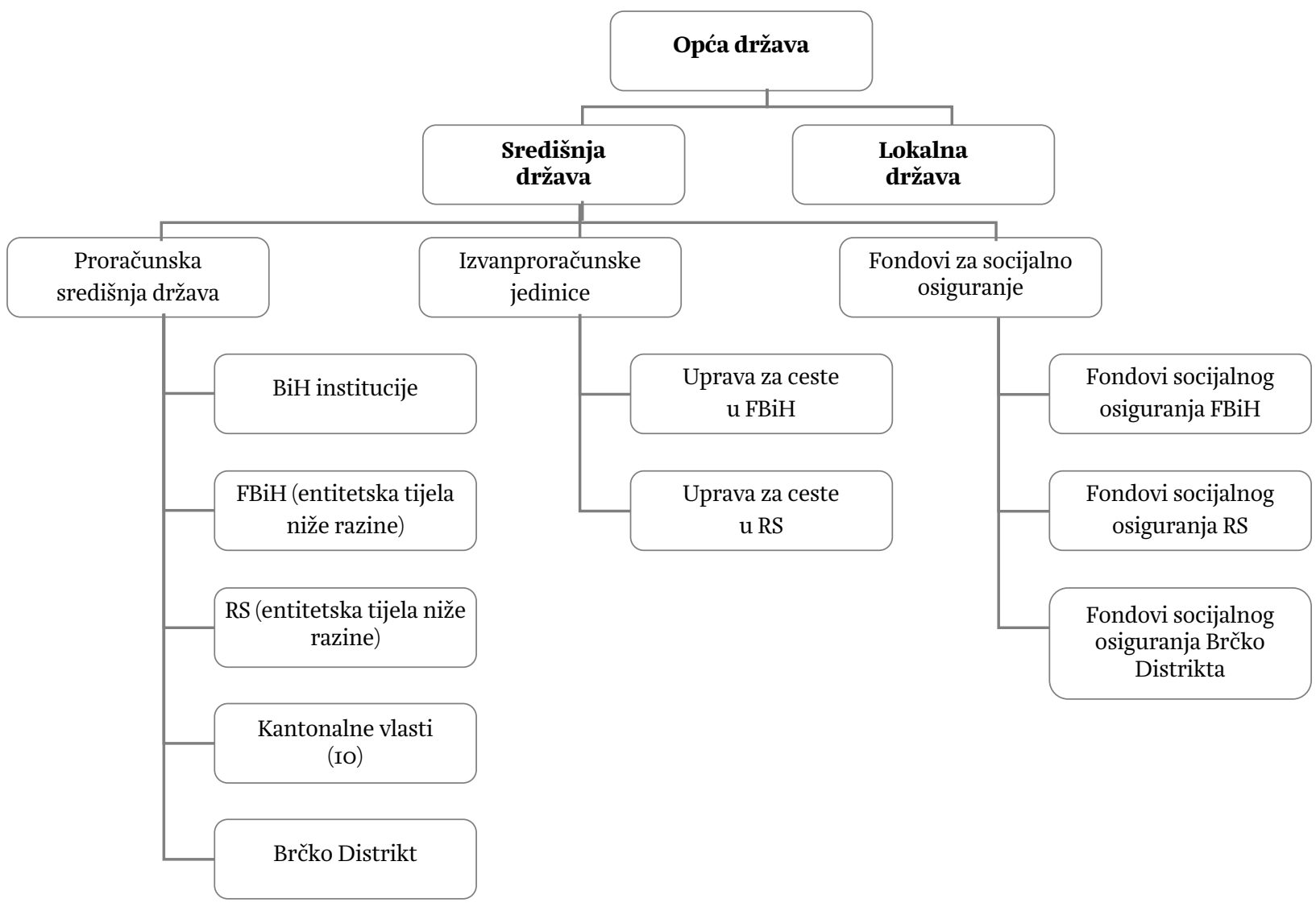

Izvor: IMF, 2005.

\section{TABLica AI.}

Konsolidirane entitetske vlasti, u \% BDP-a.

\begin{tabular}{|c|c|c|c|c|}
\hline & \multicolumn{2}{|c|}{2008} & \multicolumn{2}{|c|}{2011.} \\
\hline & $\begin{array}{c}\text { Konsolid. } \\
\text { FBiH }\end{array}$ & $\begin{array}{c}\text { Konsolid. } \\
\text { RS }\end{array}$ & $\begin{array}{c}\text { Konsolid. } \\
\text { FBiH }\end{array}$ & $\begin{array}{c}\text { Konsolid. } \\
\text { RS }\end{array}$ \\
\hline PRIHODI & 26,5 & 13,2 & 24,8 & I4.I \\
\hline Neizravni porezi & IO,9 & 5,5 & IO,O & 5.4 \\
\hline Izravni porezi & $2, \mathrm{I}$ & 1,6 & 1,8 & I,6 \\
\hline Porez na dobit & 0,5 & 0,5 & 0,5 & 0,5 \\
\hline Porez na dohodak & 1,2 & 0,8 & $\mathrm{I}, \mathrm{O}$ & $\mathrm{I}, \mathrm{O}$ \\
\hline Porez na imovinu & 0,5 & 0,2 & 0,2 & O,I \\
\hline Socijalni doprinosi & IO,I & 4,4 & 10,2 & 5,3 \\
\hline Neporezni prihodi & 2,9 & 1,6 & 2,7 & 1,7 \\
\hline Ostalo & 0,3 & $\mathrm{O}, \mathrm{I}$ & $\mathrm{O}, \mathrm{I}$ & $\mathrm{O}, \mathrm{I}$ \\
\hline RASHODI & 27,9 & I3,7 & 25,6 & 14,4 \\
\hline Tekući rashodi & 26,7 & $\mathrm{I} 2,3$ & 25,0 & 13,3 \\
\hline Plaće i naknade & 6,5 & $3, I$ & 6,4 & 3,6 \\
\hline Uporaba dobara i usluga & 5,6 & 2,7 & 5,8 & $\mathrm{I}, 2$ \\
\hline Dotacije & $\mathrm{I} 4, \mathrm{O}$ & 6,0 & $\mathrm{II}, 2$ & 7,7 \\
\hline Otplata kamata i drugih naknada & 0,3 & 0,3 & 0,4 & 0,3 \\
\hline Drugi troškovi & 0,3 & 0,2 & $\mathrm{I}, 2$ & 0,8 \\
\hline Neto stjecanje nefinancijske imovine & $\mathrm{I}, 3$ & $\mathrm{I}, 3$ & 0,6 & $\mathrm{I}, \mathrm{I}$ \\
\hline Bruto operativna bilanca & $-0,2$ & 0,9 & $-0,2$ & 0,8 \\
\hline Neto posudbe/zaduživanje & $-\mathrm{I}, 4$ & $-0,5$ & $-0,8$ & $-0,3$ \\
\hline
\end{tabular}

Izvor: Baza podataka Odjela za makroekonomsku analizu Upravnog odbora UIO-a 
TABLICA A2.

Niže razine vlasti u FBIH, $u$ \% BDP-a.

2008

2011.

\begin{tabular}{|c|c|c|c|c|c|c|}
\hline & $\begin{array}{l}\text { Proračun } \\
\text { FBiH }\end{array}$ & Kantoni & Općine & $\begin{array}{l}\text { Proračun } \\
\text { FBiH }\end{array}$ & Kantoni & Općine \\
\hline PRIHODI & 5,4 & 8,3 & $3, \mathrm{I}$ & 5,2 & 7,4 & 2,5 \\
\hline Neizravni porezi & 4,4 & 5,7 & 0,8 & 4,2 & 5,0 & 0,7 \\
\hline Izravni porezi & 0,2 & $\mathrm{I}, 3$ & 0,7 & 0,2 & $\mathrm{I}, 2$ & 0,4 \\
\hline Porez na dobit & $\mathrm{O}, \mathrm{I}$ & 0,3 & $\mathrm{O}, \mathrm{I}$ & 0,2 & 0,4 & $\mathrm{O}, \mathrm{O}$ \\
\hline Porez na dohodak & $\mathrm{O}, \mathrm{O}$ & 0,9 & 0,2 & $\mathrm{O}, \mathrm{O}$ & 0,8 & 0,2 \\
\hline Porez na imovinu & $\mathrm{O}, \mathrm{O}$ & $\mathrm{O}, \mathrm{I}$ & 0,4 & 0,0 & 0,0 & 0,2 \\
\hline Neporezni prihodi & 0,8 & $\mathrm{I}, \mathrm{O}$ & $\mathrm{I}, \mathrm{O}$ & 0,8 & 0,9 & 0,9 \\
\hline Ostalo & $\mathrm{O}, \mathrm{O}$ & 0,3 & 0,6 & $\mathrm{O}, \mathrm{O}$ & 0,2 & 0,4 \\
\hline RASHODI & 6,2 & 8,7 & 3,2 & 5,3 & 7,5 & 2,6 \\
\hline Tekući rashodi & 5,8 & 8,2 & 2,7 & 5,3 & 7,3 & 2,2 \\
\hline Plaće i naknade & $\mathrm{I}, \mathrm{O}$ & 4,5 & 0,7 & 0,9 & 4,5 & 0,7 \\
\hline Uporaba dobara i usluga & 0,3 & $\mathrm{I}, \mathrm{O}$ & 0,5 & 0,3 & 0,9 & 0,5 \\
\hline Dotacije & 4,3 & 2,7 & 1,3 & 3,6 & 1,5 & 0,5 \\
\hline Otplata kamata i drugih naknada & 0,3 & 0,0 & 0,0 & 0,3 & 0,0 & 0,0 \\
\hline Drugi troškovi & 0,0 & 0,0 & 0,2 & 0,2 & 0,4 & 0,4 \\
\hline Neto stjecanje nefinancijske imovine & 0,3 & 0,4 & 0,5 & $\mathrm{O}, \mathrm{I}$ & 0,2 & 0,4 \\
\hline Bruto operativna bilanca & $-0,4$ & $\mathrm{O}, \mathrm{I}$ & 0,4 & $-\mathrm{O}, \mathrm{I}$ & $\mathrm{O}, \mathrm{I}$ & 0,3 \\
\hline Neto posudbe/zaduživanje & $-0,8$ & $-0,4$ & $-0, I$ & $-O, I$ & $-O, I$ & $-O, I$ \\
\hline
\end{tabular}

Izvor: Baza podataka Odjela za makroekonomsku analizu Upravnog odbora UIO-a.

\section{TABLIGA A3.}

Niže razine vlasti u $R S-u, u$ \% BDP-a.

2008.

2011.

\begin{tabular}{|c|c|c|c|c|}
\hline & \multicolumn{2}{|c|}{2008.} & \multicolumn{2}{|c|}{ 20II. } \\
\hline & $\begin{array}{l}\text { Proračun } \\
\text { RS }\end{array}$ & Općine & $\begin{array}{l}\text { Proračun } \\
\text { RS }\end{array}$ & Općine \\
\hline PRIHODI & 6,3 & 2,6 & 6,3 & $2, \mathrm{I}$ \\
\hline Neizravni porezi & 4,2 & I,3 & 4,2 & $\mathrm{I}, 2$ \\
\hline Izravni porezi & $\mathrm{I}, 3$ & 0,3 & $\mathrm{I}, 3$ & 0,3 \\
\hline Porez na dobit & 0,5 & 0,0 & 0,5 & 0,0 \\
\hline Porez na dohodak & 0,7 & 0,2 & 0,7 & 0,2 \\
\hline Porez na imovinu & $\mathrm{O}, \mathrm{I}$ & $\mathrm{O}, \mathrm{I}$ & $\mathrm{O}, \mathrm{I}$ & $\mathrm{O}, \mathrm{I}$ \\
\hline Neporezni prihodi & 0,9 & 0,7 & 0,7 & 0,6 \\
\hline Ostalo & 0,0 & 0,2 & 0,0 & 0,0 \\
\hline RASHODI & 6,2 & 2,9 & 5,5 & 2,2 \\
\hline Tekući rashodi & 5,9 & I,9 & 5,0 & $\mathrm{I}, 7$ \\
\hline Plaće i naknade & 2,4 & 0,6 & 2,7 & 0,7 \\
\hline Uporaba dobara i usluga & 0,5 & 0,6 & 0,4 & 0,5 \\
\hline Dotacije & 2,7 & 0,6 & I,5 & 0,2 \\
\hline Otplata kamata i drugih naknada & 0,3 & 0,0 & 0,2 & $\mathrm{O}, \mathrm{I}$ \\
\hline Drugi troškovi & 0,2 & $\mathrm{O}, \mathrm{O}$ & 0,3 & 0,3 \\
\hline Neto stjecanje nefinancijske imovine & 0,2 & $\mathrm{I}, \mathrm{I}$ & 0,5 & 0,5 \\
\hline Bruto operativna bilanca & 0,4 & 0,7 & $\mathrm{I}, 3$ & 0,4 \\
\hline Neto posudbe/zaduživanje & O,I & $-0,3$ & 0,8 & $-\mathrm{O}, \mathrm{I}$ \\
\hline
\end{tabular}

Izvor: Baza podataka Odjela za makroekonomsku analizu Upravnog odbora UIO-a. 


\section{REFERENCE}

I. Ahmad, E., Albino-War, M. and Singh, R., 2005. Subnational Public Financial Management: Institutions and Macroeconomic Considerations. IMF Working Paper WP/O5/IO8.

2. Antić, D., 2008. Trajna raspodjela neizravnih poreza sa jedinstvenog računa UNO. Računovodstvo $i$ poslovne finansije, 32 (7-8), 5-12.

3. Antić. D., 2009. Makroekonomska stabilnost i fiskalni federalizam. Mostar: FIRCON.

4. Bahl, R. and Martinez-Vazquez, J., 20o6. Sequencing Fiscal Decentralization. Policy Research Working Paper, No.

5. Bird, R. M. and Vaillancourt, F., 2006. Perspectives on Fiscal Federalism. Washington: World Bank Publications. doi: http://dx.doi.org/IO.I596/978-0-8213-6555-7

6. Bird, R.M., 2003. Asymetric Fiscal Decentralization: Glue or Solvent?. US-Georgia: Andrew Young School of Policy Studies.

7. Blankart, C. B. and Klaiber, A., 2006. Subnational Government Organisation and Public Debt Crises [online]. Oxford: Institute of Economic Affairs : Blackwell Publishing.

8. Blöchliger, H. and Petzold, O., 2009. Taxes and Grants: On the Revenue Mix of Sub-central governments. COM/CTPA/ECO/GOV/WP(2009)7. Paris: OECD: Network on Fiscal Relations across Levels of Government.

9. Blöchliger, H. et al., 20IOa. Sub-central Governments and the Economic Crisis: Impact and Policy Responses. Economics Department Working Papers, No. 752.

IO. Blöchliger, H. et al., 2OIob. Fiscal Policy across Levels of Government in Times of Crisis. $\mathrm{COM} / \mathrm{CTPA} / \mathrm{ECO} / \mathrm{GOV} / \mathrm{WP}(2 \mathrm{OIO}) \mathrm{I2}$. Paris: OECD.

II. Boadway R. and Roberts S., 1994. The Reform of Fiscal Systems in Developing and Emerging Market Economies: A Federalism Perspective. Policy Research Working Paper No. 1259.

I2. Boadway, R. and Watts, R., 200o. Fiscal Federalism in Canada. Canada-Ontario: Institute of Intergovernmental Relations, Queen's University Kingston.

13. Chelsky J. A. and Norregaard, J., 2006. Institutional Approaches to Fiscal Coordination: What can Bosnia \& Herzegovina Learn from international experience. Bosnia and Herzegovina: Selected Issues. IMF Country Report No. 06/368. Washington: International Monetary Fund.

14. Database of Macroeconomic Analysis Unit (MAU) of the ITA Governing Board. [http://www.oma.uino.gov.ba/o4_izvjestaji.asp?1].

15. Davey, K., ed., 20II.Local Government in Critical Times: Policies for Crisis, Recovery and a Sustainable Future [online]. Dostupno na 〈http://www.ccre.org/docs/Local_Government_in_critical_times.EN.pdf $>$.

I6. Dziobek, C. et al., 20IIa. Measuring Fiscal Decentralization - Exploring the IMF's Databases. IMF WP/II/I26. Dostupno na <http://www.imf.org/external/pubs/ft/wp/2OII/wpIII26.pdf >.

17. Dziobek, G. et al., 2OIIb. The IMF's Government Finance Statistics Yearbook, Maps of Government for 74 Countries. IMF WP/II/I26 [online]. Dostupno na <http://www.imf.org/external/pubs/ft/wp/20II/wpIII27.pdf .

18. Ebel, R.D. and Yilmaz S., 2002. Concept of Fiscal Decentralisation and Worldwide Overview, texts submitted for the International Symposium on fiscal imbalance, Commission of Fiscal Imbalance, Quebec. Washington: World Bank Institute. Dostupno na <http://www.groupes.finances.gouv.qc.ca/desequilibrefiscal/en/pdf/recueil_en.pdf `.

19. European Commission, 20I2. Fiscal frameworks across Member States [online]. European Economy, Occasional Papers 9I. Dostupno na <www.ec.europa.eu/economy_finance/publications〉.

20. IMF, 200I. GFS- Government Finance Statistics Manual. Washington: International Monetary Fund.

2I. IMF, 2005. Government Finance Statistics, Yearbook 2005. Washington: International Monetary Fund.

22. IMF, 2006. Bosnia and Herzegovina: Selected issues, Country Report No. 06/368. Washington: International Monetary Fund. Dostupno na <http://www.imf.org/external/pubs/ft/scr/2006/cro6368.pdf>.

23. IMF, 2009. Bosnia and Herzegovina, Request for Stand-By Arrangement, Country Report No. 09/226 [online]. Washington: International Monetary Fund. Dostupno na <http://www.imf.org/external/pubs/ft/scr/2009/crog226.pdf .

24. IMF, 20IOa. Bosnia and Herzegovina: Letter of Intent and Technical Memorandum of Understanding [online]. Washington: International Monetary Fund. Dostupno na <http://www.imf.org/external/np/loi/20Io/bih/o305Io.pdf>.

25. IMF, 20Iob. Bosnia and Herzegovina: Selected issues [online]. Washington: International Monetary Fund. Dostupno na <http://www.imf.org/external/pubs/ft/scr/20Io/crio347.pdf〉. 
26. IMF, 20I2. Bosnia and Herzegovina: Letter of Intent, Memorandum of Economic and Financial Policies, and Technical Memorandum of Understanding [online]. Dostupno na <http://www.imf.org/external/np/loi/2OI2/bih/ogIII2.pdf>.

27. Jonas J., 2OI2. Great Recession and Fiscal Squeeze at U.S. Subnational Government Level, IMF Working Paper [online]. Dostupno na <http://www.imf.org/external/pubs/ft/wp/2OI2/wpi2I84.pdf>.

28. Joumard, I. and Kongsrud, P. M., 2003. Fiscal relations across government levels. Economics Department Working Papers No. 375.

29. Musgrave R. A., 1959. The Theory of Public Finance, A Study in Public Economy. McGrow-Hill Book Company Inc.

30. Oates, W.E., 1972. Fiscal Federalism. New York: Harcourt Brace Jovanovich.

3I. Oates, W.E., 2005. Toward A Second-Generation Theory of Fiscal Federalism. International Tax and Public Finance, I2(4), pp. 349-373. doi: http://dx.doi.org/I0.I007/sio797-005-1619-9

32. OECD, 2009a. Fiscal Autonomy of Sub-central Governments - An Update. COM/CTPA/ECO/GOV/WP(2009)9. Dostupno na <http://www.oecd.org/ctp/fiscalfederalismnetwork/42982242.pdf>.

33. OECD, 2009b. Finding the Dividing Line Between Tax Sharing and Grants: Statistical Investigation COM/CTPA/ECO/GOV/WP(2009)IO. Dostupno na <http://www.oecd.org/ctp/fiscalfederalismnetwork/43072896.pdf>.

34. Prud'homme, R., I995. The Dangers of Decentralisation. The World Bank Research Observer, Io(2), pp. 2OI-22O. doi: http://dx.doi.org/IO.IO93/wbro/IO.2.2OI

35. Rodden, J. A., 2005. Hamilton's Paradox: The Promise and Peril of Fiscal Federalism. Cambridge University Press. doi: http://dx.doi.org/Io.IOI7/CBO9780511616075

36. Shah, A., I997. Fiscal Federalism and Macroeconomic Governance: For Better or for Worse?. World Bank Policy Research Working Paper. Dostupno na $<\mathrm{http}: / /$ ideas.repec.org/p/wbk/wbrwps/2005.html>.

37. Shah, A., 200o. Issues in Tax Assignment. In: Litvack J., Seddon J. (ed.). Decentralization Briefing Notes. WBI Working Papers [online]. Dostupno na <http://siteresources.worldbank.org/WBI/Resources/wbi37I42.pdf $>$.

38. Shah, A., 2005. Fiscal Decentralization and Fiscal Performance. World Bank Policy Research Working Paper, No. 3786. Dostupno na <http://elibrary.worldbank.org/docserver/download/3786.pdf $>$.

39. Šimović, H. 2007. Fiscal system and fiscal relations in the European Union: political restraints and alternative approach to public finance. Working paper series. Paper No. 07-04 [online]. Dostupno na 〈http://web.efzg.hr/repec/pdf/Clanak\%2007-04.pdf〉.

40. Šimović., J. and Šimović, H. 2006. Fiskalni sustav i fiskalna politika Europske Unije. Zagreb: Pravni fakultet Sveučilišta u Zagrebu.

4I. Super, D. A., 2005. Rethinking Fiscal Federalism. Harvard Law Review, II8(8), pp. 257I-2579.

42. Tanzi, V., 200o. On Fiscal Federalism: Issues to worry about. Washington: International Monetary Fund.

43. Ter-Minassian, T. (ed.), 1997. Fiscal Federalism in Theory \& Practice. Washington: International Monetary Fund.

44. Ter-Minassian, T. and Fedelino A., 20Io. Impact of the Global Crisis on Sub-National Governments' Finances. Bank of Italy Research Paper Series - Occasional Papers [online]. Dostupno na 〈http://papers.ssrn.com/sol3/papers.cfm?abstract_id=1985235〉.

45. United Cities and Local Governments, 2009. The Impact of the Global Crisis on Local Governments [online]. Dostupno na <http://www.uclg.org/sites/default/files/9225580315_(EN)_uclgcrisis(eng).pdf $>$.

46. Weingast, B. R., 2006. Second Generation Fiscal Federalism: Implications for Decentralized Democratic Governance and Economic Development. Discussion paper [online]. Dostupno na $\langle$ http://papers.ssrn.com/sol3/papers.cfm?abstract_id=II53440〉.

47. Wibbels, E., 2005. Federalism and the Market: Intergovernmental Conflict and Economic Reform in the Developing World. Cambridge: Cambridge University Press. doi: http://dx.doi.org/IO.IOI7/CBO97805II5IO44I 